\title{
PREEMPTION AND PUNITIVE DAMAGES: THE CONFLICT CONTINUES UNDER FIFRA
}

\author{
Mary Lee A. Howarth $\dagger$
}

\section{INTRODUCTION}

Disputes over the allocation of regulatory power between federal and state authorities historically have plagued our system of federalism. The Framers envisioned a federal government that was centralized enough to ensure an effective national government, yet still protective of state autonomy. ${ }^{1}$ Both the explosion of federal regulatory power during the New Deal era ${ }^{2}$ and the growth of federal agencies during the 1960 s and $1970 \mathrm{~s}^{3}$ ostensibly threatened the autonomy of state power in various areas of regulation. The judiciary has responded in part to this tension by applying the doctrine of preemption. This doctrine, which is derived from the supremacy clause of the Constitution, ${ }^{4}$ determines whether federal or state regulation will reign over an area that both have attempted to control. ${ }^{5}$ Preemption has served to allocate regulatory

† B.A. 1983, Harvard College; J.D. Candidate 1988, University of Pennsylvania. During the summer of 1986, the author worked as an intern in the chambers of the judge who decided Wilson v. Chevron Chem. Co., No. 83-762 (S.D.N.Y. Dec. 17, 1986), but she did not participate in the drafting of the decision.

1 See The Federalist No. 51, at 323 (J. Madison) (C. Rossiter ed. 1961) ("In the compound republic of America, the power surrendered by the people is first divided between two distinct governments . . . . Hence a double security arises to the rights of the people. The different governments will control each other, at the same time that each will be controlled by itself.").

${ }^{2}$ See Rabin, Federal Regulation in Historical Perspective, 38 STaN. L. REv. 1189, 1243-53 (1986); Note, The Preemption Doctrine: Shifting Perspectives on Federalism and the Burger Court, 75 Colum. L. REv. 623, 624 (1975).

3 Twenty-six new federal agencies were created during the period from 1965 to 1975. L. Garter, Administrative Law and Politics 15 (1983).

4 The Constitution states:

This Constitution, and the Laws of the United States which shall be made in Pursuance thereof; and all Treatises made, or which shall be made, under the Authority of the United States, shall be the supreme Law of the Land; and the Judges in every State shall be bound thereby, any Thing in the Constitution or Laws of any State to the Contrary notwithstanding.

U.S. Const. art. VI (emphasis added).

s This Comment defines preemption to mean the invalidation of state law or some other form of state regulatory action, specifically a judicial award of punitive damages, by conflicting federal legislation. It should also be noted that invalidation through preemption "implies the existence of federal legislation," and is, therefore, distinguishable from commerce clause analysis, which invalidates a state law through a clause in the 
powers between the federal and state governments in such diverse areas as interstate transportation, ${ }^{6}$ public utilities, ${ }^{7}$ labor relations, ${ }^{8}$ and copyright. ${ }^{9}$ Only recently, however, has the preemption debate extended to the distribution of regulatory power over the labeling of chemicals that are potentially dangerous to consumers. ${ }^{10}$

Wilson v. Cheuron Chemical Co. ${ }^{11}$ and Ferebee v. Chevron Chem-

Constitution. See Note, supra note 2, at 623 n.7.

B See, e.g., Missouri Pac. R.R. v. Porter, 273 U.S. 341 (1927) (preempting state law limiting liability of carrier for damage to property carried in interstate commerce); Atchison, T. \& S.F. Ry. v. Harold, 241 U.S. 371 (1916) (same); Ghicago, R.I. \& Pac. Ry. v. Cramer, 232 U.S. 490 (1914) (same); Yazoo \& Miss. Valley R.R. v. Greenwood Grocery Co., 227 U.S. 1 (1913) (preempting state agency regulation imposing penalty for failure to deliver freight at depots within a state time limit); Adams Express Co. v. Croninger, 226 U.S. 491 (1913) (preempting state law limiting liability of carrier for damage to property carried); Southern Ry. v. Reid, 222 U.S. 424 (1912) (preempting law penalizing carriers for failure to deliver freight as soon as received).

7 See, e.g., Nantahala Power \& Light Co. v. Thornburg, 476 U.S. 953 (1986) (state utilities commission rate-making order preempted by federal law); Transcontinental Gas Pipe Line Corp. v. State Oil \& Gas Bd., 474 U.S. 409 (1986) (preempting order of state oil and gas board requiring interstate pipeline to receive fuel "ratably" from a common gas pool); Arkansas Elec. Coop. Corp. v. Arkansas Pub. Serv. Comm'n, 461 U.S. 375 (1983) (overruling earlier preemption of state action in conflict with the Federal Power Act's regulation of local power cooperatives).

8 See, e.g., Golden State Transit Corp. v. Los Angeles, 475 U.S. 608 (1986) (preempting municipality from conditioning taxi franchise renewal on the timely settlement of a labor dispute); Wisconsin Dep't of Indus., Labor \& Human Relations v. Gould, Inc., 475 U.S. 282 (1986) (preempting state law prohibiting repeat violators of NLRA from doing business with the state); Allis-Chalmers Corp. v. Lueck, 471 U.S. 202 (1985) (preempting state tort of bad faith handling of claim under a disability plan that was part of collective bargaining agreement).

${ }^{8}$ See, e.g., Compco Corp. v. Day-Brite Lighting, Inc., 376 U.S. 234, 237 (1964) ("To forbid copying would interfere with the federal policy, found in Art. I, $\S 8, \mathrm{cl}$. 8, of the Constitution and in the implementing federal statutes, of allowing free access to copy whatever the federal patent and copyright laws leave in the public domain."); Sears, Roebuck \& Co. v. Stiffel Co., 376 U.S. 225, 231-32 (1964) ("To allow a State by use of its law of unfair competition to prevent the copying of an article . . represent[ing] too slight an advance to be patented would be to permit the State to block off from the public something which federal law has said belongs to the public.").

10 This Comment examines the preemptive power of the labeling provision in the Federal Insecticide, Fungicide, and Rodenticide Act, 7 U.S.C. $\$ \S 136-136$ y (1982 \& Supp. IV 1986) ("FIFRA"), to displace an award of punitive damages in a failure-towarn tort suit, an issue that the Court has never considered. The issue arose in two recent cases, Wilson v. Chevron Chem. Co., No. 83-762 (S.D.N.Y. Dec. 17, 1986) (rejecting defendant's motion to dismiss claim for punitive damages), and Ferebee v. Chevron Chem. Co., 736 F.2d 1529 (D.C. Cir.), cert. denied, 469 U.S. 1062 (1984) (rejecting claim that FIFRA preempted compensatory damages awarded at trial), which are the focus of this Comment. The only other federal case that deals with the preemptive power of FIFRA's labeling directives is Chemical Specialties Mfrs. Ass'n Inc. v. Lowery, 452 F.2d 431 (2d Cir. 1971). Judge Friendly found that FIFRA preempted a New York City regulation with different labeling requirements. See id. at $439-40$.

11 No. 83-762 (S.D.N.Y. Dec. 17, 1986). 
ical Co. ${ }^{12}$ held that the Federal Insecticide, Fungicide, and Rodenticide Act ("FIFRA"), ${ }^{13}$ the federal law that governs the use of pesticides, does not preempt an award of punitive damages in a state tort failureto-warn suit against a pesticide manufacturer. These decisions are surprising in light of the fact that FIFRA provides a comprehensive scheme governing the labeling of pesticides and a system of fines and punishment to enforce the labeling provisions of the statute. ${ }^{14}$ Wilson and Ferebee, moreover, focus attention on the doctrinal and practical considerations in imposing liability in failure-to-warn cases against manufacturers whose labeling activities are closely regulated by the federal government. Wilson and Ferebee also are controversial preemption decisions in an era when judicial attitudes favoring the preeminence of state autonomy in questions of federalism may bring the doctrine of preemption into disfavor. ${ }^{16}$ They address preemption of punitive damage issues that have been raised in both the Third and District of Columbia Gircuits without consistent resolution. ${ }^{16}$ The decisions also raise substantial questions about preemption of punitive damages at a time when the magnitude of these awards is skyrocketing.

This Comment argues that FIFRA should preempt an award of punitive damages in failure-to-warn tort suits, contrary to the findings of the Wilson and Ferebee courts. ${ }^{17}$ Part I describes the framework of

12736 F.2d 1529 (D.C. Cir.), cert. denied, 469 U.S. 1062 (1984).

137 U.S.C. $\S \S 136-136 y$ (1982 \& Supp. IV 1986).

14 See infra notes 62-64 and accompanying text (noting the implications of a comprehensive scheme of regulation in preemption decisions).

15 See infra notes 91-106 and accompanying text (describing the hesitancy in recent Court decisions to find preemption of state action). After Garcia v. San Antonio Metro. Transit Auth., 469 U.S. 528 (1985), the Court is especially likely to hesitate to infer any limitation on state sovereignty unless Congress has explicitly and deliberately created the prohibition. See Van Alstyne, The Second Death of Federalism, $83 \mathrm{MICH}$. L. REv. 1709, 1722-24 (1985).

16 See infra notes 107-11 and accompanying text.

17 Although considerable literature has addressed preemption in many contexts, none has focused on whether FIFRA preempts state punitive damage awards. A sampling of the literature discussing the preemptive power of various other federal statutes includes Brooks, Preemption of Federal Labor Law by the Employment-at-Will Doctrine, 38 LABOR L.J. 335 (1987) (preemptive power of the NLRA); Glicksman, Federal Preemption and Private Legal Remedies for Pollution, 134 U. PA. L. REv. 121 (1985) (discussing preemption by federal environmental legislation); Note, Administrative Preemption in Consumer Banking Law, 73 VA. L. REv. 911 (1987) (National Bank Act); and Comment, Tobacco Under Fire: Developments in Judicial Responses to Cigarette Smoking Injuries, 36 CATH. U.L. REv. 643 (1987) (Federal Cigarette Labeling and Advertising Act).

This Comment takes issue with two recent notes addressing the preemption of punitive damages in the context of the Atomic Energy Act. In Note, An Analysis of Silkwood v. Kerr-McGee Corp.: Are Punitive Damage Awards and Exclusive Federal Regulation Consistent?, 36 S.C.L. REv. 689 (1985) [hereinafter Silkwood Analysis], an analysis of the preemption of punitive damages in the context of Silkwood v. Kerr- 
FIFRA, introduces the Wilson and Ferebee facts, and sketches the courts' decisions. Part II introduces the preemption doctrine and surveys the range of judicial interpretations of the concept. Part III examines the first prong of the doctrine, namely the "occupation of a field of regulation" ("occupation") approach, to determine whether preemption should occur in situations such as those in Wilson and Ferebee. This Comment argues that congressional desire to occupy exclusively the field of pesticide labeling regulation, as explicitly expressed in the legislative history and implicitly demonstrated by the comprehensive regulatory scheme contemplated by FIFRA, warrants the preemption of punitive damage awards in failure-to-warn tort cases. Part IV addresses the alternative analysis used in Wilson and Ferebee to determine whether preemption by FIFRA should occur, namely the "federal-state law conflict" ("conflict") approach. This Comment argues that due to the regulatory nature of punitive damages, such awards conflict with the effective functioning of FIFRA. This contention is reinforced by an economic analysis of the coexistence of FIFRA's com-

McGee Corp., 464 U.S. 238 (1984), and an examination of the Atomic Energy Act are provided. The Note proposes a two-step analysis for courts considering preemption claims in heavily regulated areas. First, the court should make a traditional preemption analysis. Second, if no preemption of the cause of action and punitive damages are found, the defendant's compliance with federal regulations demonstrates nonegregious behavior and, therefore, should preclude such an award. Silkwood Analysis, supra, at 716.

This Comment also considers the evidentiary impact of compliance with pervasive federal regulations on an award of punitive damages. However, a much broader preemption attack on punitive damages based on the labeling provision of an entirely different federal statute is given as well. This Comment provides a more in-depth analysis of the preemption doctrine and argues for preemption under the favorable and unfavorable interpretations of both prongs of the doctrine. It also provides a more rigorous examination of the implications of the coexistence of exemplary damages and a federal regulatory scheme that has its own punitive program. Finally, not only is a different judicial response of preemption proposed herein, but this Comment also proposes several ideas for legislative solutions to the FIFRA preemption scenario.

Another Note concerning the Atomic Energy Act is Comment, Federal Supremacy Versus Legitimate State Interests in Nuclear Regulation: Pacific Gas \& Electric and Silkwood, 33 GaTH. U.L. REv. 899 (1984), which directly conflicts with the position taken in Silkwood Analysis, supra. That Comment argues against the preemption of state regulatory and judicial action by the Atomic Energy Act and proposes an amendment to the act. The proposal would give states explicit authority to regulate nuclear materials and facilities except when such regulations conflict with federal law. See id. at 931-42. Such a scheme in the FIFRA context, however, merely begs the same question that the Wilson and Ferebee courts have faced: given a federal law that purports to distribute regulatory power between federal and state authorities, how does a court respond to overlapping or conflicting regulatory activities? This Comment proposes an amendment, but also stipulates that it contain either an explicit preemption of punitive damages in failure-to-warn tort cases or a presumption in favor of preemption in such cases. See infra notes 246-49 and accompanying text. This Comment also draws the line for such a proposal at punitive damages, thus leaving intact the ability of exposure victims to obtain compensation under state tort law. 
prehensive scheme of regulation and exemplary damages in a state tort suit. Finally, Part V concludes that the appropriate judicial response to this dilemma is a finding that FIFRA preempts the award of punitive damages. It also provides several legislative solutions to the problems that gave rise to the litigation against Chevron.

\section{FIFRA AND THE WILSON AND FEREBEE Decisions}

\section{A. The Framework of FIFRA}

The regulation of pesticides ${ }^{18}$ under FIFRA is comprehensive, particularly in the area of labeling and packaging. FIFRA requires the continuous registration of all pesticides distributed for sale in the United States. ${ }^{19}$ Registration entails extensive testing of the product by the manufacturer and the submission of these test results to the Environmental Protection Agency ("EPA"). ${ }^{20}$ FIFRA requires "the submission of enormous quantities of technical data,"21 such as "test results from studies concerning toxicity, carcinogenicity, mutagenicity, reproductive effects, effects on metabolism, environmental fate, and results of exposure to the substance, as well as results from other studies used to assess the human and environmental risks posed by a product." 22 The EPA supplements this information with its own testing, data gathering, and public hearings. ${ }^{23}$

If a state also desires to register pesticides or certify pesticide applicators, it must first obtain approval of its plan from the EPA and meet existing standards for personnel, funding, and reporting to the federal government. ${ }^{24}$ While states are given authority to regulate the sale and use of pesticides to the extent that such regulation does not

18 'The term 'pesticide' means (1) any substance or mixture of substances intended for preventing, destroying, repelling, or mitigating any pest, and (2) any substance or mixture of substances intended for use as a plant regulator, defoliant, or desiccant . . . ." 7 U.S.C. $§ 136($ u) (1982). For an overview of FIFRA's coverage and development, see M. Worobec, Toxic Substances Controls Primer: Federal Regulation of Ghemicals in the Environment 38-59 (1984).

187 U.S.G. § $136 \mathrm{a}(\mathrm{a})$, (c) (1982 \& Supp. IV 1986).

207 U.S.C. $\S 136 \mathrm{a}(\mathrm{c})(1)(\mathrm{D})$-(c)(2) (1982 \& Supp. IV 1986).

21 F. Anderson, D. Mandelker \& A. Tarlock, Environmental ProtecTION: LAW AND POLICY 540 (1984).

${ }^{22} \mathrm{M}$. WOROBEC, supra note 18 , at 45 . Registrants must also disclose trade secrets, a requirement that has generated substantial litigation. See, e.g., Thomas v. Union Carbide Agricultural Prods. Co., 473 U.S. 568 (1985); Ruckelshaus v. Monsanto Co., 467 U.S. 986 (1984); McGarity \& Shapiro, The Trade Secret Status of Health and Safety Testing Information: Reforming Agency Disclosure Policies, 93 HaRv. L. Rev. 837, 879 (1980).

237 U.S.C. $\$ \S 136 \mathrm{a}(\mathrm{c})(2)(\mathrm{A}), 136 \mathrm{~s}$ (1982).

24 7 U.S.C. $\S 136 b(a)(2)(1982)$. 
conflict with FIFRA, ${ }^{26}$ the EPA is given exclusive authority to regulate the more specialized areas of labeling and packaging. ${ }^{26}$ FIFRA also outlaws state regulation of pesticide use that is inconsistent with federal labeling requirements, ${ }^{27}$ thus giving the EPA concurrent control over pesticide use. ${ }^{28}$

When a pesticide manufacturer violates either the general requirements of FIFRA or the specific guidelines that the EPA has created for particular products, the EPA will notify the United States Attorney General who, in turn, will institute criminal or civil proceedings against the violator. ${ }^{29}$ Among other things, FIFRA makes it unlawful to sell or distribute a pesticide that is unregistered, falsify registration information, or alter the EPA approved composition of the product. $^{30}$ In addition, any unilateral effort to "detach, alter, deface, or destroy, in whole or in part, any labeling required under" FIFRA constitutes a violation of the law, ${ }^{\mathbf{3 1}}$ although a label may be legally changed by petitioning for and obtaining EPA approval. ${ }^{32}$ Finally, FIFRA authorizes the EPA to assess a civil penalty on violators of the statute of up to of $\$ 5,000$ per offense. ${ }^{38}$ Criminal prosecution may follow a knowing violation of FIFRA; a prosecution may result in imprisonment, a fine of not more than $\$ 25,000$, or both. ${ }^{34}$ In this statutory setting, the litigation in Wilson v. Chevron Chemical Co. ${ }^{35}$ and Ferebee v. Cheoron Chemical Co. ${ }^{36}$ commenced.

\section{B. The Wilson and Ferebee Decisions}

On November 13, 1982, Scott Wilson died of injuries resulting from exposure to a pesticide that occurred during his employment as a landscaper. The chemical, Ortho Paraquat CL ("OPCL"), is distributed exclusively in this country by the Chevron Ghemical Company ("Chevron"). Mr. Wilson's widow filed a diversity suit against Chevron claiming negligence, breach of warranty, and strict products liability. She sought to recover $\$ 17$ million in compensatory damages and

25 7 U.S.C. \& 136v(a) (1982).

${ }^{28}$ See 7 U.S.C. \& $136 \mathrm{v}(\mathrm{b})(1982)$.

27 See 7 U.S.C. $\$ 136 j(a)(2)(G)(1982)$.

28 See M. WOROBEC, supra note 18 , at 45.

${ }^{29}$ See 7 U.S.C. $\& 136 \mathrm{~g}(\mathrm{c})(1)(1982)$.

so See 7 U.S.C. \& 136j(a)(1)(A), (1)(G), (2)(M) (1982).

s1 See 7 U.S.C. \& 136j(a)(2)(A) (1982).

s2 See Wilson v. Chevron Chem. Co., No. 83-762, slip op. at 4 (S.D.N.Y. Dec. $17,1986)$.

3s See 7 U.S.C. $\S 136 l(a)(1)(1982)$.

s4 See 7 U.S.C. $\$ 136 l(\mathrm{~b})(1)(1982)$.

${ }^{35}$ No. 83-762 (S.D.N.Y. Dec. 17, 1986).

s8 736 F.2d 1529 (D.C. Cir.), cert. denied, 469 U.S. 1062 (1984). 
$\$ 20$ million in punitive damages. ${ }^{37}$ Mrs. Wilson asserted that Chevron had "failed to adequately warn of the hazards of dermal exposure to OPCL." As As a result, her husband allegedly absorbed the pesticide through his skin in fatal proportions. Chevron countered that the decedent had died of ingesting OPCL, against which OPCL's label had given an explicit warning. ${ }^{38}$

Chevron also moved for partial summary judgment on the issue of punitive damages. It alleged, based on a theory of federal preemption of state action, that punitive damages were precluded as a matter of law. ${ }^{40}$ The company argued that punitive damages arising from a state law failure-to-warn tort claim are regulatory in nature and, therefore, are preempted by the federal regulations governing OPCL. ${ }^{41}$ Preemption, Chevron asserted, is required by the comprehensive federal scheme set out in FIFRA that has governed OPGL since $1966^{42}$ Under the statute, the EPA is given extensive authority to regulate the registration, sale, and use of pesticides, and exclusive control over pesticide labeling. ${ }^{43}$

The facts in Ferebee are strikingly similar to those in Wilson. Richard Ferebee, an agricultural employee for the United States Department of Agriculture, used a Chevron paraquat product "regularly" over a three-year period. ${ }^{44}$ On several occasions, his skin was exposed to the paraquat; indeed, Mr. Ferebee once used a defective spraying apparatus that "leaked paraquat solution all over his pants."45 Subsequently, Mr. Ferebee developed pulmonary fibrosis and died on March $18,1982 . .^{46}$ After a trial that resulted in an award of only $\$ 60,000$ in compensatory damages, ${ }^{47}$ Chevron appealed, claiming that FIFRA pre-

37 See Wilson, slip op. at 3-4.

38 Id. at 5 .

so See id. at 5 n.*.

to See id. at 2.

4 See id. at 11. For purposes of Chevron's motion, the court decided that Florida law would apply. See id. at 7-8.

42 See id. at 4.

4s See id. at 4; 7 U.S.C. §§ 136-136y (1982 \& Supp. IV 1986). The Wilson court also found that "Chevron has at all times complied with FIFRA and EPA regulations regarding the labelling and registration of OPCL." Wilson, slip op. at 4. Since 1975, OPCL has been classified by the EPA as a "restricted use" pesticide, which requires that all users of the product be "trained and certified pesticide applicator[s]" or under such a person's supervision. Id. Scott Wilson was neither a certified pesticide applicator nor was he working under the supervision of such an individual at the time of his exposure to OPGL. See id.

44 See Ferebee, 736 F.2d at 1531-32.

15 Id. at 1532.

16 See id. at 1532-33. Medical experts at the Ferebee trial testified that paraquat exposure had caused Ferebee's pulmonary fibrosis. See id. at 1533.

${ }^{47}$ See Ferebee v. Chevron Chem. Co., 552 F. Supp. 1293, 1297 \& n.17 (D.D.C. 
empted a damage action based on a state failure-to-warn tort claim. ${ }^{48}$

In analyzing the preemptive power of FIFRA, both the Wilson and Ferebee courts employed the contemporary, two-pronged preemption analysis recently enunciated in Silkwood v. Kerr-McGee Corp. ${ }^{48}$ The Silkwood Court refused to find federal preemption of a punitive damage award. According to Silkwood, preemption can be ascertained in either of two ways. First, "[i]f Congress evidences an intent to occupy a given field, any state law falling within that field is preempted." $"$ Alternatively,

[i]f Congress has not entirely displaced state regulation over the matter in question, state law is still pre-empted to the extent it actually conflicts with federal law, that is, when it is impossible to comply with both state and federal law . . . or where the state law stands as an obstacle to the accomplishment of the full purposes and objectives of Congress. ${ }^{.1}$

Silkwood, however, analyzed the preemptive posture of the Atomic Energy Act, ${ }^{52}$ leaving the Wilson and Ferebee courts free to determine the preemptive power of FIFRA, the law regulating OPCL. The occupation analyses in these decisions were limited to examinations of the text and legislative history of the relevant FIFRA provisions and yielded the conclusion that Congress did not intend to dominate the regulation of pesticide labeling. ${ }^{\mathrm{s}}$ The Wilson and Ferebee courts then explored the alternative method of finding preemption, taking their cue from the conflict analysis in Silkwood, which required preemption only when it was "physically impossible" to comply with potentially conflicting state

1982) (denying Chevron's motion for judgment notwithstanding the verdict).

48 See Ferebee, 736 F.2d at 1532.

48464 U.S. 238 (1984) (upholding award of punitive damages for the survivor of an employee who died from plutonium exposure at a nuclear facility subject to the Atomic Energy Act).

${ }^{50}$ Id. at 248 (citing Pacific Gas \& Elec. Co. v. State Energy Resources Conservation \& Dev. Comm'n, 461 U.S. 190, 203-204 (1983); Fidelity Fed. Sav. \& Loan Ass'n v. De la Cuesta, 458 U.S. 141, 153 (1982); Rice v. Santa Fe Elevator Corp., 331 U.S. 218, 230 (1947)).

51 Id. (citing Pacific Gas \& Elec., 461 U.S. at 204; Florida Lime \& Avocado Growers, Inc. v. Paul, 373 U.S. 132, 142-43 (1963); Hines v. Davidowitz, 312 U.S. 52, $67(1941))$.

${ }_{52}$ See id. at 257-58. The statute at issue in Silkwood was the Atomic Energy Act of 1954, Pub. L. No. 83-703, 68 Stat. 919 (codified as amended in scattered sections of 42 U.S.C.).

${ }_{53}$ By limiting the occupation test to a strict statutory construction analysis, these courts made it quite difficult to establish preemption. The Court has considered other factors, such as the importance of uniformity in regulation, to determine whether Congress intended to occupy a field of regulation. See infra text accompanying notes 62-69 \& 85-90. 
and federal directives. ${ }^{54}$ Since it was not impossible for Chevron to pay tort damages and comply with FIFRA, the courts reasoned, Chevron's alternative claim to preemption was rejected. ${ }^{.5}$

\section{The Role of Preemption}

\section{A. The Doctrine}

The doctrine of preemption, which is derived from the supremacy clause of the Constitution, ${ }^{\mathbf{6}}$ addresses the distribution of regulatory power between the federal and state governments when their efforts overlap. Interpretations of the concept, though, have historically been so inconsistent that one commentator has questioned "whether the doctrine controls the subject matter, or the subject matter the doctrine."157 'In simplest form, the doctrine states that a federal law preempts or displaces any state law that conflicts with a federal directive. ${ }^{\mathrm{s}}$ The preemption question is largely a matter of statutory construction that has evolved into two alternative approaches for determining whether Congress intended that federal law should preempt state action. First, a

s4 See Silkwood, 464 U.S. at 257. The Wilson court actually relied directly on Ferebee for the District of Columbia Circuit's conflict analysis, which in turn relied on Silkwood. See Wilson, slip op. at 13.

ss See Ferebee, 736 F.2d at 1541-42; Wilson, slip op. at 13-15. The Wilson court concluded, moreover, that questions of fact still existed regarding the specifics of Chevron's behavior during the labeling and testing process. See Wilson, slip op. at 16. On March 25, 1988, as this Comment was going to print, the jury in the Wilson trial found Chevron liable for negligence, breach of warranty, and strict products liability. Mrs. Wilson was awarded $\$ 4,089,769.43$ in compensatory damages and no punitive damages. Verdict Sheet and Special Interrogatories, Wilson v. Chevron Chem. Co., (S.D.N.Y. Mar. 25, 1988) (No. 83-762).

so See Gibbons v. Ogden, 22 U.S. (9 Wheat.) 1, 24 (1824); see also supra note 4 (text of the supremacy clause).

57 Note, supra note 2 , at 649.

68 Conflict between federal and state law is ordinarily the exception, not the norm. As Professors Hart and Wechsler have stated:

Federal law is generally interstitial in its nature. It rarely occupies a legal field completely, totally excluding all participation by the legal systems of the states. . . . Federal legislation, on the whole, has been conceived and drafted on an ad hoc basis to accomplish limited objectives. It builds upon legal relationships established by the states, altering or supplanting them only so far as necessary for the special purpose. Congress acts, in short, against the background of the total corpus juris of the states in much the way that a state legislature acts against the background of the common law, assumed to govern unless changed by legislation.

P. Bator, P. Mishinin, D. Shapiro \& H. Wechsler, Hart and Wechsler's The Federal Courts and the Federal System 470-71 (2d ed. 1973). This Comment acknowledges the interstitial nature of federal regulation but argues that the federal government intended to control the regulation of pesticide labeling within the entire federal-state framework of pesticide regulation. 
federal law will displace a state regulation or action if Congress intended to occupy the field of regulation at issue. ${ }^{5 \theta}$ Alternatively, a federal law will preempt a state law if the latter conflicts either with the functioning or the objectives of a federal law. ${ }^{\mathbf{B O}}$

Various shadings of congressional intent to occupy a field of regulation have been found to have preemptive power. The clearest expression of preemption, of course, occurs when Congress expresses its exclusive jurisdiction in the language of a statute. For example, the Court determined that the language in the Wholesome Meat Act, forbidding the imposition of " [m]arking, labeling, packaging, or ingredient requirements in addition to, or different than, those made under" " federal law, was indicative of congressional intent to occupy exclusively the field of labeling bacon packages. ${ }^{61}$ Even if a state law supports federal goals, that state law may still be invalidated if Congress has arro- . gated to itself the jurisdiction over regulation in a particular area.

The nature and importance of a particular regulated field also may imply or require exclusive federal control. State action in this instance may be preempted by a federal scheme even before that scheme becomes operative. ${ }^{62}$ The Court, moreover, will consider various qualities of the regulatory framework when-deciding whether a state action in the same area should be displaced. For example, the more pervasive a scheme of federal law, the more likely it is that Congress intended to occupy the field of regulation. ${ }^{63}$ Indeed, the Court has articulated the

so See 1 R. Rotunda, J. NowaK \& J. Young, Treatise on Constitutional Law: Substance and Procedure $\S \S 12.1,12.4$ (1986) [hereinafter R. Rotunda]; G. Stone, L. Seidman, G. Sunstein \& M. Tushnet, Constitutional Law 319 (1986) [hereinafter G. Stone]; L. TRIBE, AMERICAN Constitutional LAw § 6-25 (2d ed. 1988). Preemption under both prongs of the doctrine generally is considered an issue of statutory construction, though subject to shifting modes of construction and, as suggested earlier, to shifting perspectives on federalism. See L. TRIBE, supra, \& 6-25; Note, supra note 2, at 623-24.

60 See 1 R. Rotunda, supra note 59 , 12.1 ; G. STONE, supra note 59 , at 319 ; L. TRIBE, supra note 59, §6-25.

B1 Jones v. Rath Packing Co., 430 U.S. 519, 530 (1977) (quoting the Fair Meat Inspection Act, Pub. L. No. 90-201, § 16, 81 Stat. 584, 600 (1967) (codified at 21 U.S.C. $\S 678(1982)))$.

62 See Erie R.R. v. New York, 233 U.S. 671, 681-83 (1914) (congressional regulation of a field brings it under exclusive federal control); Northern Pac. Ry. v. Washington, 222 U.S. 370, 378-79 (1912) (enactment of statute manifests will of Congress to bring subject within its control).

${ }_{63}$ See, e.g., Amalgamated Ass'n of St., Elec. Ry. \& Motor Coach Employees v. Lockridge, 403 U.S. 274, 296 (1971) ("federal concern is pervasive and its regulation complex" in regard to the "applicable union security clause"); Castle v. Hayes Freight Lines, 348 U.S. 61, 63 (1954) (The Motor Carrier Act "was so all-embracing that former power of states over motor carriers was greatly reduced. No power at all was left in States to determine what carriers could or could not operate in interstate commerce."). 
assumption that " $[\mathrm{t}]$ he scheme of federal regulation may be so pervasive as to make reasonable the inference that Congress left no room for the States to supplement it." ${ }^{\text {"64 }}$

The very existence of a federal regulatory agency, moreover, may weigh in favor of preemption through the occupation approach. ${ }^{86}$ For example, the Federal Communications Commission's policy of preventing radio and television stations from censoring the statements of political candidates preempted state libel actions against the local stations that broadcast such statements. ${ }^{66}$ The creation of a federal agency "may signify a congressional determination that some jurisdictionally-definable aspect of the regulated subject matter demands uniform national supervision and that the judicial grant to the states of jurisdiction to act is, to that degree, legislatively withdrawn." ${ }^{\prime \prime 7}$ The Court, for instance, has dismissed a state tort action for damages caused by a labor union's picketing in the context of a preemption claim. ${ }^{68}$ The importance of national uniformity in the regulation of concerted activities and unfair labor practices under federal law precludes state action reaching such activities because that action might frustrate Congress' national labor policy goals. ${ }^{69}$

The alternative route to preemption is available if a state law or

64 Rice v. Santa Fe Elevator Corp., 331 U.S. 218, 230 (1947).

6s See, e.g., Capital Cities Cable, Inc. v. Crisp, 467 U.S. 691, 700 (1984) (Federal Communications Commission "has resolved to pre-empt an area of cable television regulation"; therefore, "all conflicting state regulations have been precluded" (footnote omitted)); Fidelity Fed. Sav. \& Loan Ass'n v. De la Guesta, 458 U.S. 141, 162 (1982) (the Home Owners' Loan Act of 1933 gave the Federal Home Loan Bank Board such broad authority that the Court refused to find confinement of the Board's authority to preempt state law to those areas "specifically described by the Act's other provisions" (citation omitted)); United States v. Shimer, 367 U.S. 374, 377 (1961) (Veterans Administration regulations clearly "intended to create a uniform system for determining the Administration's obligation as guarantor, which in its operation would displace state law.").

${ }^{6 B}$ See Farmers Educ. \& Coop. Union v. WDAY, Inc., 360 U.S. 525, 535 (1959).

${ }^{67}$ L. TRIBE, supra note 59 , \& 6-28.

${ }^{68}$ See San Diego Bldg. Trades Council v. Garmon, 359 U.S. 236 (1959).

${ }^{60}$ See id. at 242-43. But see Farmer v. United Bd. of Carpenters, 430 U.S. 290, 295-301 (1977) (rejecting preemption claim that National Labor Relations Act precluded state action for infliction of emotional distress, and noting that the federal interest in regulating labor relations was distinct enough from the state interest in tort remedy as to reduce the possibility of state interference with the federal regulatory program); Linn v. United Plant Guard Workers Local 114, 383 U.S. 53, 61 (1966) (rejecting preemption claim that a defamation suit resulting from a union-organizing campaign could not be brought in state court and recognizing " an overriding state interest ' in protecting its [state] residents from malicious libels"); Head v. New Mexico Bd. of Examiners in Optometry, 374 U.S. 424, 429-32 (1963) (comprehensive federal regulation under Federal Communications Act did not preempt state injunction against local broadcaster; state regulations were complementary to federal law). 
initiative conflicts with federal law. ${ }^{30}$ Federal-state conflict may take a number of forms, with express preemption representing one extreme on a continuum of conflict situations. Express preemption occurs when Congress acknowledges that a conflicting state law exists and expressly preempts or overrides the state action. ${ }^{71}$ In that event, a court simply analyzes the language of the federal statute in order to determine whether preemption is appropriate. Moving away from this extreme is the situation where Congress has not expressly acknowledged a conflict with state law, but it is nevertheless impossible to comply with state and federal directives that purport to control the same behavior. For example, the Court has held in this regard that a state cannot fine or punish retailers who sell out-of-state syrup that was labeled in compliance with federal law when such labeling conflicted with the labeling requirements of the retailer's state. ${ }^{72}$

More subtle forms of federal-state conflict occur when state actions conflict with the objectives of federal regulations. The question thus posed is whether the state law "stands as an obstacle to the accomplishment and execution of the full purposes and objectives of Congress."73 A corollary to this is the invalidation of a state action that elicits conduct that discourages compliance with or the success of a federal law. ${ }^{\mathbf{7 4}}$ For example, the Court struck down a state law governing the labeling of packaged flour sold within the state because it inhibited the accomplishment of the goals of the Federal Fair Packaging and Labeling Act, most importantly the reduction in consumer confusion about products from different states. ${ }^{75}$ It should be noted, finally, that state action that

${ }^{70}$ See supra note 60 and accompanying text.

${ }_{71}$ See, e.g., Federal Employee Retirement Income Security Act of 1974 (ERISA), Pub. L. No. 93-406, § 514(a), 88 Stat. 829, 897 (codified at 29 U.S.C. $§ 1144$ (a) (1982)) ("Except as provided in subsection (b) of this section, the provisions of this subchapter and subchapter III of this chapter shall supercede any and all state laws insofar as they may now or hereafter relate to any employee benefit plan . . . ."). Litigation often arises over the scope of state activities covered by the preemption provision. See, e.g., Shaw v. Delta Air Lines, 463 U.S. 85, 96 (1983) (finding that federal law that expressly preempted state laws to extent that they "'relate to' employee benefit plans" related to and preempted state antidiscrimination statute (quoting ERISA)).

${ }^{72}$ See McDermott v. Wisconsin, 228 U.S. 115, 131-32 (1913).

${ }_{73}$ Hines v. Davidowitz, 312 U.S. 52, 67 (1941); see also Nash v. Florida Indus. Comm'n, 389 U.S. 235, 239 (1967) (invalidating state law that denied unemployment benefits to eligible recipients because they had filed an unfair labor practice charge under federal labor law).

74 See, e.g., Gity of Burbank v. Lockheed Air Terminal, 411 U.S. 624, 627-28 (1973) (ordinances imposing curfews on jet flights would lead to bunching of flights immediately preceding the curfew, " a result [which] is totally inconsistent with the objectives of the federal statutory and regulatory scheme" " (quoting Lockheed Air Terminal v. City of Burbank, 11 Av. L. Rep. (CCH) 17,910, 17,918 (C.D. Cal. 1970) (Finding of Fact If 78))).

75 See Jones v. Rath Packing Co., 430 U.S. 519, 524, 542 (1977). 
merely supplements federal law without frustrating the goals of the federal scheme will not be preempted. ${ }^{76}$ These more subtle forms of conflict require examination of not only statutory language but also legislative history and regulatory structure and.context in order to determine the intended scope and purpose of the federal regulation.

\section{B. "Shifting Perspectives" and New Factors}

One commentator has urged that preemption is a constitutional doctrine that is particularly susceptible to changing interpretations-interpretations that correlate with changes in the Court's view of federalism. ${ }^{77}$ During the 1930 s and early 1940 s, the Court exhibited a preference for protecting state action in the context of preemption. Preemption by the occupation standard required "an expression of specific intent to occupy the field."78 The conflict standard required a high degree of actual conflict between state and federal law before that federal law would override state law or action. ${ }^{79}$ Moreover, the standard required the balancing of the state and federal interests at stake; the Court usually favored protecting the autonomy of the states in traditional activities such as police power. ${ }^{80}$

From the 1940 s to the early 1970s, the Court adopted interpretations of these approaches that were much more favorable to preemption claims. The conflict approach developed into a "potential conflict" approach. ${ }^{81}$ For example, in Pennsylvania $v$. Nelson, ${ }^{82}$ the Court preempted Pennsylvania's antisedition law because of the potential for inconsistent outcomes in sedition cases in different courts using different procedures. $^{83}$ The balancing of federal and state interests in the previ-

${ }^{76}$ See, e.g., Colorado Anti-Discrimination Comm'n v. Continental Air Lines, 372 U.S. 714, 722-24 (1963) (upholding state law prohibiting discriminatory hiring); California v. Zook, 336 U.S. 725, 730, 735-38 (1949) (upholding state regulation outlawing transportation not licensed by the ICG).

77 See Note, supra note 2. The Note tracks interpretations from the 1930 s to the mid-1970s, providing a chronological ordering of the spectrum of preemption interpretations just explored. Another commentator has suggested that the Court's historical inconsistency in preemption decisions is explained by the fact that the Court "bases its decision[s] on the pre-emption ground in order to avoid reaching some other constitutional question." Note, Pre-emption as a Preferential Ground: A New Canon of Construction, 12 STAN. L. Rev. 208, 210 (1959).

${ }^{78}$ Note, supra note 2, at 627.

79 See id.

${ }^{80}$ See id. at 628-30.

81 See id. at 636 \& n.83.

82350 U.S. 497 (1956).

83 See id. at 509. With regard to the occupation standard of preemption analysis, the Court emphasized the comprehensiveness of the federal statute at issue, the Smith Act of 1940, the national nature of the sedition problem, and the difficulties that would arise in state and federal administration of sedition regulation. See id. at 502-07. 
ous era was supplanted by a presumption of federal supremacy best articulated by Chief Justice Warren: "The relative importance to the State of its own law is not material when there is a conflict with a valid federal law, for the Framers of our Constitution provided that the federal law must prevail." 84

Growing federal preeminence was also evident in litigation over Congress' intent to occupy a field of regulation. Hines $v$. Davidowitz ${ }^{85}$ established that a state law is preempted when it "stands as an obstacle to the accomplishment and execution of the full purposes and objectives of Congress." $"$ With this decision the Court "substituted a purportedly objective assessment of the needs attending a statute's operation for the practice of defining the occupied field through total reliance upon Congress' subjective will.',87 Various factors enjoyed influence in the Court's occupation analyses during this period. Qualities such as the pervasiveness of the federal regulation, the importance of the national interest being regulated, ${ }^{88}$ and the unobstructed functioning of federal law were "invoked on an ad hoc basis to justify particular preemptive decisions." considerations, such as fairness to the interested parties, when the occupation and conflict approaches failed to answer the question of federal preemption. ${ }^{90}$

During the 1970s, however, the Court again displayed significant deference to state interests, resembling the view implicit in the preemption cases decided during the 1930s and early 1940s. ${ }^{91}$ The "potential

st Free v. Bland, 369 U.S. 663, 666 (1962) (citing U.S. CoNST. art. VI, § 2).

80312 U.S. 52 (1941).

${ }^{86} I d$. at 67.

87 Note, supra note 2, at 631 .

88 "When the Federal Government completely occupies a given field or an identifiable portion of it . . . the test of preemption is whether 'the matter on which the State asserts the right to act is in any way regulated by the Federal Act." "Pacific Gas \& Elec. Co. v. State Energy Resources Conservation \& Dev. Comm'n, 461 U.S. 190, 21314 (1983) (quoting Rice v. Santa Fe Elevator Corp., 331 U.S. 218, 236 (1947)).

${ }^{89}$ Note, supra note 2, at 633 (citing City of Burbank v. Lockheed Air Terminal, 411 U.S. 624 (1973) (pervasive federal regulation of air commerce); Teamsters Local 20 v. Morton, 377 U.S. 252 (1964) (pervasive federal regulation of labor relations); Teamsters Local 174 v. Lucas Flour Co., 369 U.S. 95 (1962) (same)).

90 See, e.g., Amalgamated Ass'n of St., Elec. Ry. \& Motor Coach Employees v. Lockridge, 403 U.S. 274, 286 (1971) (emphasizing uniform substantive law in labor regulation); Farmers Educ. \& Coop. Union v. WDAY, Inc., 360 U.S. 525, 533 (1959) (considering fairness to local broadcasters subject to both federal and state control); San Diego Bldg. Trades Council v. Garmon, 359 U.S. 236, 241-245 (1959) (stressing the importance of national labor policy and of avoiding inconsistent standards of law between state tort damages and federal authorities); Garner v. Teamsters Local 776, 346 U.S. 485, 490-91 (1953) (same).

o1 See Note, supra note 2 , at 639-51. 
conflict" standard of the Warren era was limited, ${ }^{92}$ and the Court showed a renewed willingness to balance state and federal interests. ${ }^{93}$ The occupation approach began to reflect a presumption of state regulatory jurisdiction when Congress failed, by legislative silence, to regulate a given area. ${ }^{94}$ As the Court stated in New York State Department of Social Services $v$. Dublino," "[w]here coordinate state and federal efforts exist within a complementary administrative framework, and in the pursuit of common purposes, the case for federal pre-emption becomes a less persuasive one."

This deference to state action has continued through the present, ${ }^{97}$

92 See id. at 647 .

9s See id. at 649-50.

ot See id. at 643-44.

98413 U.S. 405 (1973).

98 Id. at 421.

97 See, e.g., CTS Corp. v. Dynamics Corp. of Am., 107 S. Ct. 1637 (1987) (holding that state antitakeover law was not preempted by Williams Act); California Fed. Sav. \& Loan Ass'n v. Guerra, 107 S. Ct. 683 (1987) (refusing to hold that federal civil rights laws preempt state law providing pregnancy disability benefits because there was no conflict between state requirements and a federal law that provides a floor below which state benefits may not drop); Fisher v. Berkeley, 475 U.S. 260 (1986) (refusing to find that Sherman Antitrust Act preempted state anticompetition law); Midlantic Nat'l Bank v. New Jersey Dep't of Envtl. Protection, 474 U.S. 494 (1986) (refusing to preempt state environmental law forbidding abandonment of land prior to decontamination despite explicit provision in federal bankruptcy law allowing abandonment); Container Corp. of Am. v. Franchise Tax Bd., 463 U.S. 159 (1983) (refusing to preempt state franchise tax in absence of federal law designed to regulate state taxation); Arkansas Elec. Coop. Corp. v. Arkansas Pub. Serv. Comm'n, 461 U.S. 375 (1983) (overruling earlier preemption of state action in conflict with the Federal Power Act's regulation of local power cooperatives); Commonwealth Edison Co., v. Montana, 453 U.S. 609, 634 (1981) (rejecting preemption claim when state action merely conflicted with "general expressions of 'national policy' "); Maryland v. Louisiana, 451 U.S. 725, 746 (1981) (stating a reluctance to infer preemption in questionable cases because "Congress did not intend to displace state law"); Hisquierdo v. Hisquierdo, 439 U.S. 572, 581 (1979) (refusing to preempt state family law unless it does "major damage" to "clear and substantial" federal interests); Malone v. White Motor Corp., 435 U.S. 497 (1978) (declining to preempt state pension statute with predecessor federal law even though successor federal law expressly preempted state law); Ray v. Atlantic Richfield Co., 435 U.S. 151 (1978) (refusing to preempt state law requiring tankers in local waters to have more stringent safety features than required by federal law because state law achieved safety without changing safety design, which is an area of exclusive federal control). But see, e.g., Allis-Chalmers Corp. v. Lueck, 471 U.S. 202 (1985) (preempting state tort of bad faith handling of an insurance claim that was covered by federal labor law); Shaw v. Delta Airlines, Inc., 463 U.S. 85 (1983) (holding that ERISA preempts aspect of state law that prohibited discrimination on the basis of pregnancy when practice was lawful under federal law); Local 926, Int'l Union of Operating Eng'rs v. Jones, 460 U.S. 669 (1983) (finding state tort action against union claiming that union interfered with the plaintiff's employment contract was preempted by federal labor law); Fidelity,Fed. Sav. \& Loan v. De la Cuesta, 458 U.S. 141 (1982) (finding that federal regulation of savings and loan associations preempted state common law rule prohibiting use of due-on-sale clauses); Chicago \& N.W. Transp. Co. v. Kalo Brick \& Title Co., 450 U.S. 311 (1981) (preempting state award of damages to local carrier in- 
most notably with two decisions interpreting the preemptive force of the Atomic Energy Act. ${ }^{98}$ In Pacific Gas \& Electric Co. v. State Energy Resources Conservation and Development Commission, ${ }^{89}$ the Court declined to preempt a state moratorium on construction of nuclear power plants because Congress had failed to prohibit state actions that might frustrate or undercut Congressional goals. ${ }^{100}$ The Court rejected. preemption despite a finding that "the Federal Government has occupied the entire field of nuclear safety concerns, except the limited powers expressly ceded to the States, "101 and despite the clear federal objective of promoting nuclear power through the Atomic Energy Act. ${ }^{102}$ In Silkwood v. Kerr-McGee Corp., ${ }^{103}$ the Court declined to find that the Atomic Energy Act preempted an award of punitive damages to the survivors of a nuclear power plant employee who was exposed to plutonium, again despite a finding that Congress intended to occupy the field of nuclear safety and despite Kerr-McGee's compliance with federal safety requirements. ${ }^{104}$ The Court stated that it was the defendant's burden to show that Congress "expressly supplanted" the traditional state function of awarding punitive damages, and nothing in the legislative history demonstrated this directive. ${ }^{105}$ The Court also imposed a prodigious obstacle for preemption claimants who argue that a state directive conflicts with federal law. Preemption, the Court stated, would not be appropriate unless it was "physically impossible" to simultaneously comply with federal and state requirements. ${ }^{108}$

The Silkwood Court's refusal to preempt punitive damages has led to disagreement among the circuits in failure-to-warn cases. Ferebee $v$. Chevron Chemical Co., ${ }^{107}$ as explained earlier, closely followed Silkwood and rejected the argument that FIFRA preempted state tort compensatory damages. ${ }^{108}$ The Third Circuit, however, declined to use the conflict analysis adopted by the Ferebee court in Cipollone v. Lig-

jured by interstate carrier's abandonment of rail line); Jones v. Rath Packing Co., 430 U.S. 519 (1977) (preempting state law governing food labels because it conflicted with federal labeling requirements).

${ }^{88}$ Pub. L. No. 83-703, 68 Stat. 919 (1954) (codified as amended in scattered sections of 42 U.S.C.).

99461 U.S. 190 (1983).

100 See id. at $220-23$.

${ }_{102}$ Id. at 212.

102 See id. at 221.

103464 U.S. 238 (1984).

104 See id. at $249-51$.

108 See id. at 255.

106 See id. at 257.

107736 F.2d. 1529 (D.C. Cir.), cert. denied, 469 U.S. 1062 (1984).

${ }^{108}$ See supra notes $44-55$ and accompanying text. 
gett Group, Inc. ${ }^{108}$ In Cipollone, the Third Circuit found that federal law preempted stricter state cigarette package labeling requirements because Congress did not intend for cigarette manufacturers to choose between federal product safety requirements and paying tort damages. ${ }^{110}$ The Third Gircuit focused on the conflict with the objectives and functioning of the federal law approach exemplified by Hines, instead of the physical impossibility test imposed by Silkwood.111

\section{PREEMPTION BY FIFRA: \\ The Occupation of a Field of Regulation Standard}

Wilson v. Chevron Chemical Co. ${ }^{112}$ and Ferebee v. Cheoron Chemical Co. ${ }^{113}$ are symptomatic of the recent judicial hesitancy to find preemption of state action. Both decisions were based on the narrow interpretations of the occupation and conflict standards exemplified by the preemption analysis in Silkwood v. Kerr-McGee Corp. ${ }^{114}$ The occupation analyses of FIFRA offered by the Wilson and Ferebee courts, however, present a number of problems. The courts' refusal to preempt tort damages can also be criticized in light of both the narrow and liberal approaches to preemption espoused at different times by the Court.

\section{A. Congressional Intent}

Both the Wilson and Ferebee courts initiated their investigations of preemption by FIFRA with an examination of the language and legislative history of the statute, in order to determine whether Congress intended to occupy the field of pesticide labeling regulation. The Wilson court began by examining the language of the relevant FIFRA provision, Section 24(b), which was added in 1972. According to this Section, states "shall not impose or continue in effect any requirements for labeling and packaging in addition to or different from those required

109789 F.2d 181 (3d Cir. 1986), cert. denied, 107 S. Ct. 907 (1987).

110 See id. at 186-88. Cipollone is consistent with a more recent Court decision preempting the traditional state function of providing tort remedies. In Allis-Chalmers Corp. v. Lueck, 471 U.S. 202, 220-21 (1985), the Court found preemption of the Wisconsin tort of bad faith handling of an insurance claim in the context of a collective bargaining agreement and, presumably, the remedies that might arise through liability because federal labor law provided procedures for resolution of insurance disputes.

11 See Note, Common Law Claims Challenging Adequacy of Cigarette Warnings Preempted under the Federal Cigarette Labeling and Advertising Act of 1965: Cipollone v. Liggett Group, Inc., 60 ST. John's L. Rev. 754, 767 (1986).

112 No. 83-762 (S.D.N.Y. Dec. 17, 1986).

118736 F.2d. 1529, cert. denied, 469 U.S. 1062 (1984).

114464 U.S. 238 (1984). 
pursuant to this Act."11s The Wilson court apparently assumed that the scope of this prohibition reached only as far as legislatively-created labeling requirements. The Ferebee court dealt with this issue more directly by asserting that a state may not legislatively impose additional labeling requirements: "FIFRA does not allow states directly to impose additional labelling requirements . . ."116 The District of Columbia Circuit, however, then explained that state action that has the effect of changing federal labeling requirements is permissible because it falls within the states" power to regulate the "sale or use" of pesticides authorized in the previous subsection of FIFRA. ${ }^{117}$

Such a reading of FIFRA, however, conflicts with the language and legislative history of the statute. First, the language of Section 24(b) can be interpreted as a broad prohibition on state interference with federal efforts to label pesticides. Any labeling "requirement" conceivably covers a variety of state actions that interfere with or put additional burdens on FIFRA's labeling requirements, including the award of punitive damages in a successful tort action. In the view of the Court, common law remedies are no more immune from preemption than are legislatively enacted statutes. ${ }^{118}$ As the Court stated in the context of examining the preemptive powers of the National Labor Relations Act:

Our concern is with delimiting areas of conduct which must be free from state regulation if national policy is to be left unhampered. Such regulation can be as effectively exerted through an award of damages as through some form of preventive relief. . . . It may be that an award of damages in a

118 Federal Environmental Pesticide Control Act of 1972, § 24(b), Pub. L. No. 92-516, 86 Stat. 973, 997 (codified as amended as part of FIFRA at 7 U.S.C. $\S 136 \mathrm{v}(\mathrm{b})(1982))$.

${ }_{116}$ Ferebee, 736 F.2d at 1541 (emphasis added).

117 See id. Section 24(a) of FIFRA reads: "A State may regulate the sale or use of any pesticide or device in the State, but only if and to the extent the regulation does not permit any sale or use prohibited by this subchapter." 7 U.S.G. $\$ 136 \mathrm{v}(\mathrm{a})$ (1982).

118 See, e.g., Pilot Life Ins. Co. v. Dedeaux, 107 S. Ct. 1549, 1554-55 (1987) (preempting common law breach of contract and tort claims against insurance company that improperly processed benefits claim); Chicago \& N.W. Transp. Co. v. Kalo Brick \& Tile Co., 450 U.S. 311, 317-31 (1981) (preempting Iowa's common law action for damages against rail carrier that abandoned railroad lines); Lodge 76, Int'l Ass'n of Machinists v. Wisconsin Employment Relations Comm'n, 427 U.S. 132, 138-39 (1976) (preempting state injunction prohibiting union from refusing to work overtime). Indeed, in the area of labor relations, early cases suggested that preemption of state common law was more acceptable than displacement of state statutes enacted to regulate labor activities. See Amalgamated Ass'n of St., Elec. Ry. \& Motor Coach Employees v. Lockridge, 403 U.S. 274, 290-91 (1971) (citing Automobile Workers v. Russell, 356 U.S. 634, 635 (1958)). Punitive damages, in any case, are codified in several states. See infra note 178 and accompanying text. 
particular situation will not, in fact, conflict with the active assertion of federal authority. The same may be true of the incidence of a particular state injunction. To sanction either involves a conflict with federal policy in that it involves allowing two law-making sources to govern. In fact, since remedies form an ingredient of any integrated scheme of regulation, to allow the State to grant a remedy here . . . only accentuates the danger of conflict. ${ }^{119}$

It is unlikely, moreover, that Congress would have designated federal control over labeling in Section 24(b) if it thought that the provision should be thwarted by state action ostensibly authorized by Section 24(a). This is supported by the definition of the term "to use any registered pesticide in a manner inconsistent with its labeling" that Congress provided at the beginning of FIFRA. ${ }^{120}$ The term means, quite simply, "to use any registered pesticide in a manner not permitted by the labeling." ${ }^{\prime 21}$ Congress thereby specified what uses were consistent with federal labeling and outlawed those that were inconsistent. ${ }^{122}$ Thus, Section 24(b) may prohibit not only direct state regulation of labeling but also indirect state action that has the effect of adding additional requirements to those of the statute.

A closer look at FIFRA's legislative history also indicates that no provision of the statute condones state action that has the effect of requiring more stringent labeling requirements. The Senate Report ${ }^{\mathbf{2 3}}$ quoted in both Ferebee ${ }^{124}$ and Wilson ${ }^{125}$ refers to subsections (a) and (c) of FIFRA Section 24, which give states the authority to "regulate the sale or use" of a pesticide and allow states that are certified by the EPA to aid the agency in the pesticide registration process. ${ }^{126}$ The very same paragraph of the Senate Report states, however, that "[s]ubsection (b) preempts any State labeling or packaging requirements differing from such requirements under the Act." ${ }^{127}$ There is no indication that

119 San Diego Bldg. Trades Council v. Garmon, 359 U.S. 236, 246-47 (1959).

1207 U.S.C. § 136(ee) (1982).

121 Id. (emphasis added). The definition goes on to exclude uses that are condoned by the product's EPA-approved label and uses that are authorized by other sections of FIFRA.

122 See 7 U.S.C. $\& 136 j(a)(2)(G)(1982)$ (declaring it unlawful "to use any registered pesticide in a manner inconsistent with its labeling").

${ }_{123}$ See S. Rep. No. 92-838, 92d Cong., 2d Sess. 30, reprinted in 1972 U.S. CodE

Cong. \& ADMIN. News 3993, 4021.

124 See Ferebee, 736 F.2d at 1541.

125 See Wilson, slip op. at 12.

128 See 7 U.S.C. \& 136v(a), (c) (1982) (emphasis added).

127 S. REP. No. 92-838, 92d Cong., 2d Sess. 30, reprinted in 1972 U.S. CoDE Cong. \& ADMIN. NEwS 3993, 4021. 
Congress intended for its explicit statement of federal control over labeling to be circumvented by other provisions of the statute that give different regulatory responsibilities to the states. Indeed, the Senate Report indicates that the federal government intended to retain exclusive authority over labeling and packaging, "preempt[ing]," in the Senate's phrasing, any state requirements to the contrary.

The historical development of pesticide regulation and FIFRA also demonstrate a congressional intent to preempt state regulation of the labeling and packaging of pesticides. Lawmakers, in fact, have long believed that the manufacture, use, and packaging of chemical pesticides required more uniform, "[f]ederal regulation for the protection of users, consumers and the general public."128 In 1947, Congress promulgated FIFRA and assigned regulatory jurisdiction over pesticides to the United States Department of Agriculture ("USDA"). ${ }^{129}$ In 1962, the publication of Rachel Carson's Silent Spring, ${ }^{130}$ which criticized the USDA's enforcement of pesticide law, alerted many to the importance of pesticide control. ${ }^{131}$ During the 1960 s, growing concern over the public health and ecological effects of pesticides led to a number of efforts to increase federal control over pesticide regulation. These efforts culminated in a presidential advisory commission on pesticides, the creation of the Environmental Protection Agency, and amendments to FIFRA in the 1960 s and 1970 s. $^{132}$ The Court has recently reviewed the historical development of FIFRA and noted: "As first enacted, FIFRA was primarily a licensing and labeling statute . . . . [Recent] amendments transformed FIFRA from a labeling law into a comprehensive regulatory statute."13s

${ }^{128}$ Id. at 7, reprinted in 1972 U.S. Code Cong. \& ADMIN. NEws 3993, 3999. Congress passed a precursor to FIFRA, the Federal Insecticide Act of 1910, ch. 191, 36 Stat. 331. In 1946, the Council of State Governments urged the states to adopt a model pesticide statute, the Uniform State Insecticide, Fungicide, and Rodenticide Act. That same year, Congress began hearings on "more comprehensive Federal legislation," which would make uniform the pesticide regulations adopted by various states. See S. ReP. No. 92-838, 92d Cong., 2d Sess. 7, reprinted in 1972 U.S. CoDE Cong. \& ADMIN. NEws 3993, 3999.

128 See M. WOROBEc, supra note 18 , at 40.

190 R. Carson, Silent Spring (1962).

131 See Megysey, Governmental Authority to Regulate the Use and Application of Pesticides: State vs. Federal, 21 S.D.L. Rev. 652, 653 (1976). See generally R. CARsoN, supra note 130, at 91-92, 156-61, 275 (criticizing the USDA).

${ }_{132}$ See S. REP. No. 92-838, 92d Cong., 2d Sess. 8-9, reprinted in 1972 U.S. Code Cong. \& Admin. News 3993, 4001. Another Senate Report also noted the urgent need for strengthening the federal regulation of pesticides. See S. REP. No. 92970, 92d Cong., 2d Sess. 9, reprinted in 1972 U.S. Code Cong. \& ADmIN. News $4092,4093$.

1ss Ruckelshaus v. Monsanto Co., 467 U.S. 986, 991 (1984); see also Thomas v. Union Carbide Agric. Prods. Co., 473 U.S. 568, 571-75 (1985) (detailing the history of 
This analysis of FIFRA's legislative history is not meant to imply that federal statutes that preempt state regulations must be overwhelmingly federal in nature. On the contrary, a number of federal statutes that are considered cooperative ventures between federal and state governments are still considered federally preeminent. ${ }^{134}$ A House of Representatives report on the 1972 amendments to FIFRA indicates that FIFRA is cast from the same mold. It states that the improved FIFRA

establishes a coordinated Federal-State administrative system to carry out the new program. The States are given prime responsibility for the certification and supervision of pesticide applicators. The Federal Government sets the program standards the States must meet. State authority to change Federal labeling and packaging is completely preempted, and State authority to further regulate 'general use' pesticides is partially preempted. ${ }^{138}$

The House hearings on the 1972 amendments to FIFRA also contained a discussion of this delicate but important concern over the division of regulatory responsibility between the states and the federal government. ${ }^{136}$ The House report reiterated that "[i]n dividing responsibility ... for the management of an effective pesticide program, the Committee [on Agriculture] has adopted language which is intended to completely preempt State authority in regard to labeling and packaging."137 Hence, a more complete survey of FIFRA's legislative history demonstrates that while specific aspects of pesticide regulation have clearly been left to the states, Congress intended exclusively to regulate pesticide labels. Contrary to the findings of the Wilson and Ferebee courts,

\section{FIFRA).}

${ }^{134}$ Federal statutes often contain a "savings clause" that allows complementary regulation by the states. See 1 R. RotundA, supra note 59, at $\S 12.1$. For example, the Securities Exchange Act of 1934 states:

Nothing in this chapter shall affect the jurisdiction of the securities commission (or any agency or officer performing like functions) of any State over any security or any person insofar as it does not conflict with the provisions of this chapter or the rules and regulations thereunder.

15 U.S.C. $\$ 78 \mathrm{bb}($ a) (1982); see also CTS Corp. v. Dynamics Corp. of Am., 107 S. Ct. 1637, 1653 (1987) (Scalia, J., concurring in part and in the judgment) (Securities Exchange Act of 1934 "forecloses pre-emption on the basis of conflicting 'purpose' as opposed to conflicting 'provision" "). Indeed, the notion of "cooperative federalism" implies a cooperation between state and federal authorities in the regulation of a particular field. See Pierce, Regulation, Deregulation, Federalism, and Administrative Law: Agency Power to Preempt State Regulation, 46 U. PITT. L. REv. 607, 645 (1985).

${ }_{135}$ H. REP. No. 92-511, $92 d$ Cong., 2d Sess. 1-2 (1972) (emphasis added).

136 See id. at 16.

${ }^{137} I d$. (emphasis added). 
Congress did intend to occupy the field of labeling regulation.

\section{B. Congressional Objectives}

1. The Role of the EPA

As the foregoing analysis of FIFRA's legislative history indicates, Congress explicitly indicated that the federal government should retain exclusive control over pesticide labeling. This intention is also implicit in the regulatory framework established by Congress to govern these chemicals. It is significant, for example, that Congress considered the regulation of pesticides so important that it created the EPA to promulgate and enforce environmental regulations. Congress also supplies the EPA with substantial annual funding and staffing in order for it to develop the expertise needed to test new pesticides and develop safe product labels. This scheme is further evidence that Congress intended that the federal government occupy the field of labeling regulation. ${ }^{138}$ The Court's assessment of the role of the NLRB in labor regulation is analogous to the labeling function of the EPA in the FIFRA context: "[T] $\mathrm{T}$ he unifying consideration of our [preemption] decisions has been regard to the fact that Congress has entrusted administration of the labor policy for the Nation to a centralized administrative agency, armed with its own procedures, and equipped with its specialized knowledge and cumulative experience."139

The preemption issue in the FIFRA context, however, juxtaposes the EPA's expertise in labeling not against the expertise of a state environmental agency or a state legislature but against a lay state jury. A liability verdict coupled with a punitive damage award defines the line between a safe label and an illegal label and identifies which aspects of a defendant's behavior the jury finds particularly egregious. ${ }^{140} \mathrm{It}$ is unlikely that this line will be static, however, as various juries may not define a legal label on a consistent basis. Such outcomes might also disregard the cost-benefit mode of decisionmaking that Congress authorized the EPA to use and that characterizes much environmental legislation. ${ }^{141}$ Juries, moreover, are not likely to possess the expertise agency).

${ }^{138} \mathrm{Cf}$. cases cited supra note 65 (noting the implications of a strong federal

${ }^{139}$ San Diego Bldg. Trades Council v. Garmon, 359 U.S. 236, 242 (1959).

${ }^{140}$ This Comment argues that punitive damages are regulatory in nature, supporting the assertion made here that a punitive award regulates or defines legal labeling behavior. See infra text accompanying notes 167-203.

${ }^{141}$ See F. ANDERSON, D. Mandelker \& A. TARLOCK, supra note 21, at 519, 542-45; Rogers, Benefits, Costs, and Risks: Oversight of Health and Environmental Decisionmaking, 4 HaRv. EnVT'L L. Rev. 191, 206-14 (1980). 
needed to provide sufficiently instructive and safe warnings. The extensive testing conducted by the EPA and pesticide manufacturers indicates that such an endeavor is beyond the abilities of a lay jury. The consolidation of pesticide regulation under FIFRA is consistent with this contention, as the expertise of the well-funded EPA has long been considered by Congress to be superior to that of even state regulatory bodies. ${ }^{142}$ The consistency and expertise required for labeling provide further evidence that Congress intended to leave regulation of labeling to the federal government.

A corollary to the significance of federal labeling expertise is the pervasiveness of the EPA's role in labeling. The labeling process is an entirely cooperative project between the EPA and the manufacturer: they work together to develop a safe label based on shared test data. ${ }^{\mathbf{1 4 3}}$ The final label, though, must be approved by the EPA. Indeed, a oneword variation from the approved label could result in punishment of the manufacturer under FIFRA. This pervasive control over the labeling process indicates that Congress had no desire to allow states to redefine the standard of safe labeling that is developed by the EPA and further supports congressional intent to occupy the field of pesticide regulation. . $^{144}$

\section{National Uniformity in Labeling}

The importance of national uniformity in labeling also underscores the congressional desire to occupy the field of pesticide labeling regulation. When Congress makes a legislative determination that national uniformity in supervision is required to fulfill its objectives, it indicates that Congress arrogated to itself the jurisdiction to regulate a given field. ${ }^{145}$ Different state and federal standards obviously threaten uniformity. When a court is faced with conflicting federal and state directives, it must resolve, as did the Court in San Diego Building Trades

${ }^{142}$ See S. ReP. No. 92-838, 92d Cong., 2d Sess. 8-9, reprinted in 1972 U.S. Code Cong. \& ADMin. News 3993, 4021.

143 Some commentators, however, have suggested that federal regulatory agencies typically act at the behest of the industries they purport to regulate. Proponents of this "capture theory" claim that regulations serve the interest of industry rather than the interests of consumers, workers, and other supposed beneficiaries of regulatory programs. See generally P. QUIRK, INDUSTRY INFLUENCE IN FEDERAL REgulation 17593 (1981) (analyzing the incentives of regulators); K. Schlozman \& J. TIERNEY, ORGANIZED INTERESTS AND AMERICAN DEMOCRACY (1986) (discussing the mechanics of capture theory); Stewart, The Reformation of American Administrative Law, 88 HARV. L. REv. 1667, 1684-87 (1975) (arguing that capture theory oversimplifies explanations of regulatory behavior).

${ }_{14}$ Cf. cases cited supra note 63 (noting the implications of pervasive regulation).

${ }^{145}$ See San Diego Bldg. Trades Council v. Garmon, 359 U.S. 236, 244-47 (1959). 
Council v. Garmon, "the potential conflict of two law-enforcing authorities, with the disharmonies inherent in two systems, one federal the other state, of inconsistent standards of substantive law and differing remedial schemes."148 Judicial resolutions are likely to vary considerably, further frustrating the scheme of regulation designed by Congress.

The achievement of national uniformity in the regulation of pesticide labeling is especially important. Assume, for example, that Chevron is faced with a number of unconsolidated tort claims arising out of consumer use of OPCL. Exposure victims bring suits in ten states claiming that OPCL's label failed to warn of the hazards of dermal exposure. Assume further that Chevron is found not liable in three states, but it is found liable in the rest of the cases based on a variety of different applications of substantive law. The liability verdicts, furthermore, are based on different aspects of the OPCL label and different activities of Chevron concerning the labeling of OPGL. Several questions now arise: What will Chevron put on its label when faced not only with an EPA-approved label, but also with ten state labeling standards, each defined differently by tort verdicts and varying punitive awards? How will Chevron react, for example, when Alabama decides that defective warning $A$ on OPCL's label and the behavior needed to formulate it are egregious enough to warrant punitive damages, while New Jersey regards warning $A$ as safe but finds warning $B$ and the behavior needed to formulate it worthy of punishment? Furthermore, what if Pennsylvania also finds warning $B$ punishable, yet awards only half the damages that the New Jersey case awarded ? $^{\text {147 }}$

146 Id. at 242.

147 To the extent that either failure-to-warn claims are pursued in state courts that do not follow the transaction-based joinder approach of the Federal Rules of Civil Procedure or that these claims are brought in forums that allow such joinder but deem it inappropriate in this instance, multiple, inconsistent adjudications may result. If, however, joinder is available, a plaintiff may join with another plaintiff similarly injured by OPCL to prosecute her claim, thereby reducing the potential for the numerous inconsistent outcomes hypothesized above. Similarly, plaintiffs injured by OPCL could pursue a class action in federal or state court against Ghevron and reduce the possibility of multiple labeling standards. Consolidation is problematic, though, when injuries occur in a number of different states, making the application of one state's law to the consolidated claim inappropriate. See, e.g., Phillips Petroleum Co. v. Shutts, 472 U.S. 797,822 (1985) (finding application of Kansas law to plaintiffs in eleven states injured by large gas leak "sufficiently arbitrary and unfair as to exceed constitutional limits," and remanding for further consideration of choice of law); see also Miller \& Crump, Jurisdiction and Choice of Law in Multistate Class Actions after Phillips Petroleum Co. v. Shutts, 96 YALE L.J. 1, 57-67 (1986) (detailing the problems generated by choice of law rules for class actions after Shutts). If a number of different state laws are ultimately applied to as many plaintiffs, the possibility of conflicting labeling standards remains. See generally Seltzer, Punitive Damages in Mass Tort Litigation: Addressing 
Chevron may respond to this scenario by using different labels in different states that may or may not comply with EPA requirements. Chevron might also gear its label exclusively to the label standards dictated by claims in heavy agricultural states, perhaps ignoring the labeling standards set by FIFRA and by tort cases in industrial states with few failure-to-warn claims. At the very least, this situation can cause confusion among manufacturers concerning what types of labels to produce and what type of behavior from which to refrain. Inconsistent and unpredictable labeling by manufacturers clearly obstructs the achievement of the congressional goal of protecting the public through safe, well-tested pesticide labels.

The potential for confusion among manufacturers has derivative consequences for consumers. Assume again that Chevron uses different labels in different states, and that a label's warning is a function of the number and magnitude of failure-to-warn punitive awards in that state. The flow of interstate commerce, however, may put several states' labels on one shelf. A proliferation of different labels could cause significant consumer confusion regarding the trustworthiness of any particular label or warning. Consequently, FIFRA's goal of consumer safety is threatened by the coexistence of federal and state labeling standards. This threat is yet another indication that Congress intended to occupy the field of pesticide labeling regulation.

\section{Distinguishing Silkwood}

Despite these indications that Congress intended to occupy the field of pesticide labeling regulation, Silkwood still stands as an obstacle to FIFRA's preemption of punitive damages. Silkwood, it will be recalled, rejected a claim of preemption of punitive damages despite a finding that "the Federal Government has occupied the entire field of nuclear safety concerns, except the limited powers expressly ceded to the states."148 The Court's holding largely depended on the legislative history of the Price-Anderson Act, ${ }^{149}$ which provided a scheme for partial

the Problems of Fairness, Efficiency and Control, 52 FoRDhaM L. REv. 37 (1983) (surveying these and other issues relating to punitive awards in various mass tort scenarios). For a description of the mass toxic tort litigation arising from the herbicide Agent Orange, see P. Schuck, Agent Orange on Trial: Mass ToXic Disasters in the CourTs (1987).

${ }^{148}$ Silkwood, 464 U.S. at 249 (quoting Pacific Gas \& Elec. Co. v. State Energy Resources Conservation \& Dev. Comm'n, 461 U.S. 190, 212 (1983)).

149 Pub. L. No. 85-256, 71 Stat. 576 (1957) (codified in scattered sections of 42 U.S.C.); see also Duke Power Co. v. Carolina Environmental Study Group, Inc., 438 U.S. 59, 87-94 (1978) (sustaining the constitutionality of the Price-Anderson Act in the face of due process and equal protection challenges). 
federal indemnification of operators of licensed nuclear facilities. Since the Price-Anderson Act implicitly assumed that victims of nuclear injury could still pursue state tort remedies, the Court reasoned, such remedies were not preempted and merely complemented the partial federal indemnification scheme. ${ }^{160}$

There is other evidence in the history of the Price-Anderson Act, however, that indicates that Congress contemplated the continuing existence of only compensatory damages and not exemplary awards. As the Senate stated, the statute created " 'a practical approach to the necessity of providing adequate protection against liability arising from atomic hazards as well as a sound basis for compensating the public for any possible injury of damage arising from such hazards.' "151 The Court may have mistaken congressional statements regarding compensation as covering the entire remedial scheme available in state tort law, instead of only reparative damages. It is far from clear, then, that Congress intended to preserve the states' ability to punish nuclear plant operators or that the Silkwood Court's refusal to preempt such damages was correct. ${ }^{152}$

Silkwood may also be viewed as a show of deference to the traditional exclusivity of the states in resolving tort disputes. "Punitive damages have long been a part of traditional principles of state tort law," according to the Court, and will not be displaced unless "expressly supplanted." 153 This stance is consistent with the Court's recent hesitancy to preempt state law. ${ }^{154}$ The development of punitive damages in this country, however, indicates that punishing tort defendants is not a traditional aspect of tort law. ${ }^{155}$ At the very least, punishment is a less

150 See Silkwood, 464 U.S. at 251-56 (discussing the Price-Anderson Act amendments to the Atomic Energy Act of 1954, Pub. L. No. 83-703, 68 Stat. 919 (codified as amended in scattered sections of 42 U.S.C.)).

${ }^{151}$ SEN. REP. No. 296, 85th Cong., 1st Sess. 8, reprinted in 1957 U.S. CODE Cong. \& ADMIN. News 1803, 1810 (emphasis added) (quoting testimony of Lewis L. Strauss, Chairman, Atomic Energy Commission).

${ }_{152}$ See Silkwood Analysis, supra note 17, at 711-14; see also Silkwood, 464 U.S. at 266 (Blackmun, J., dissenting) (Silkwood turns not on whether a victim can be compensated under state law, but rather whether "the jury can impose a fine on a nuclear operator in addition to whatever compensation award is given.").

153 Silkwood, 464 U.S. at 255.

154 See supra notes 91-106 and accompanying text.

165 For an in depth discussion of the nature and development of punitive damages, see infra text accompanying notes 167-203. In 1983, Justice Rehnquist provided the following description of punitive damages in the context of deciding whether such awards are available under 42 U.S.C. \$ 1983 (1982):

Despite these attempted justifications, the doctrine of punitive damages has been vigorously criticized throughout the Nation's history. Countless cases remark that such damages have never been "a favorite of the law." The year after $\S 1983$ was enacted, the New Hampshire Supreme 
"traditional" function of the remedial scheme in tort than compensation. ${ }^{156}$ As such, the preemption of punitive damages poses less of a threat to state autonomy than the preemption of compensation and deserves a preemption analysis distinct from the broad sweep of "traditional" state tort law principles. ${ }^{167}$

In addition to the anomalies of Silkwood, the application of Silkwood is arguably inappropriate in an occupation analysis of FIFRA. As an initial matter, the EPA's control over every word on OPCL's label is more pervasive than federal control over nuclear plant safety. The importance of national uniformity, moreover, is much more compelling in the labeling context. The success of a label, which is determined by whether persons with diverse comprehension abilities will understand and follow label warnings, would be undermined by a proliferation of labels. ${ }^{188}$ In addition, the legislative history of the Atomic Energy Act has no bearing on whether Congress intended to occupy-the field of pesticide labeling regulation, and in any case, there is no indication in FIFRA's legislative history that Congress assumed that punitive damages would continue to be available in state tort suits. ${ }^{169}$ On the contrary, the existence of FIFRA's comprehensive system of enforcement and punishment, whereby the Attorney General pursues civil, and in some instances, criminal actions, indicates that Congress intended the federal government to control the punishment of unacceptable labeling behavior. ${ }^{160}$ Congress, put simply, did not invite

Court declared: "The idea of [punitive damages] is wrong. It is a monstrous heresy. It is an unsightly and unhealthy excrescence, deforming the symmetry of the body of the law."

Smith v. Wade, 461 U.S. 30, 58 (1983) (Rehnquist, J., dissenting) (footnotes omitted) (quoting Fay v. Parker, 53 N.H. 342, 382 (1872)).

${ }_{188}$ It is also difficult to square the Silkwood Court's deference to a traditional domain of state law after the Court abandoned its attempt to define "traditional" spheres of state action in Garcia v. San Antonio Metro. Transit Auth., 469 U.S. 528, 537-47 (1985).

${ }_{157}$ The Silkwood decision glosses over the distinction between compensatory and punitive damages and "proceeds as if pre-emption of punitive damages would require pre-emption of compensatory damages as well." 464 U.S. at 267 (Blackmun, J., dissenting). This Comment asserts the importance of this distinction and proposes the preemption of exemplary awards coupled with the preservation of compensation in state tort law.

${ }^{158}$ See Hadden, Labeling of Chemicals to Reduce Risk, LAw \& CoNTEMP. ProBs., Summer 1983, at 235, 261 ("Since the efficacy of labels as a risk control device depends on their being understood and used by readers, existence of a multiplicity of labeling systems undermines the purpose of labels.").

${ }_{150}$ See supra notes 115-37 and accompanying text (reviewing the language and legislative history of FIFRA).

${ }_{180} C$ f. Automobile Workers v. Russell, 356 U.S. 634, 646 (1958) (implying that a federal punitive scheme could preempt state punishment since the absence of a federal punitive scheme does not preempt state authority to punish). 
the states to join in enforcement or any other aspect of labeling regulation. ${ }^{\mathbf{1 6 1}}$

This interpretation of the existence of direct punishment provisions in FIFRA has a certain equitable allure. As one commentator has argued, it is unfair for a state jury to punish activities of manufacturers in highly regulated industries. ${ }^{162}$ Compliance with pervasive federal regulations demonstrates nonegregious behavior by a defendant that is unworthy of punitive damages. ${ }^{163}$ This argument is certainly convincing in the context of a failure-to-warn claim based on a label whose every word must be approved by the federal government. The federal government alone should monitor activities that are directed by it or are the product of its intervention, as well as impose fines and other punishments when labeling behavior is unacceptable. ${ }^{164}$

\section{Preemption and FifRA: The Conflict Wrth State Law Standard}

\section{A. The Nature of Punitive Damages and the Tension With FIFRA}

The alternative avenue for preempting punitive damages in a state failure-to-warn claim is establishing that such state action conflicts with valid federal law. The courts in Wilson v. Chevron Chemical Co. ${ }^{185}$ and Ferebee v. Cheoron Chemical $\mathrm{Co}^{168}$ unfortunately did not examine the relatively simple case of a federal statute that explicitly overrides a clearly conflicting state statute. They analyzed, rather, the more subtle conflict between the implicit regulation that exemplary fines impose and the regulatory scheme established by FIFRA. A careful review of the nature and function of punitive damages in tort law will demonstrate that these awards conflict with the objectives and operation of FIFRA and should be displaced by federal law in the pesticide labeling context.

161 An employer has successfully argued that the Occupational Safety and Health Act, 29 U.S.C. 667(b) (1982), preempts state criminal prosecutions of officials at a manufacturing firm. See People v. Chicago Magnet Wire Corp., 510 N.E.2d 1173, 1175-76 (Ill. App. Ct.), appeal granted, 515 N.E.2d 115 (Ill. 1987).

162 See Silkwood Analysis, supra note 17, at 712.

${ }^{163}$ See $i d$. at 716 . Indeed, it is debatable whether such behavior is even negligent enough for tort liability.

${ }_{164} C f$. Chicago \& N.W. Transp. Co. v. Kalo Brick \& Tile Co., 450 U.S. 311, 326 (1981) ("It would be contrary to the language of the [Interstate Commerce Act] to permit litigation challenging the lawfulness of the [defendant's actions] when the Commission has expressly found them to be reasonable.").

${ }^{263}$ No. 83-762 (S.D.N.Y. Dec. 17, 1986).

166736 F.2d 1529 (D.C. Cir.), cert. denied, 469 U.S. 1062 (1984). 


\section{Punitive Damages}

Traditionally, an award of damages in a tort action served to compensate the victim: ${ }^{167}$

A person injured by the commission of a tort is entitled to actual pecuniary compensation for the injury sustained ... . He is not to be placed in a better position than he would have been in had the wrong not been done. Only such damages are recoverable for a tort as can be shown with reasonable certainty and as are the direct, natural, and proximate consequences of the defendant's wrongful act. ${ }^{168}$

Historically, tort damages were awarded to put the plaintiff in the position she would have been had she not been injured. Damages in excess of full compensation were denied, as such awards were considered an unconstitutional taking of private property. ${ }^{169}$

The original compensatory purpose of the tort remedy, however, was supplanted with punitive and other "remedial goals." One theory asserts that punitive damages evolved from a remedy known in both Roman and English common law as "multiple damages,"170 which were often imposed to punish defendants whose torts involved outrageous behavior ${ }^{171}$ or as a justification for damages that were obviously in excess of the amounts required to compensate plaintiffs. ${ }^{172}$ Other early cases awarded extra or punitive damages to compensate for intangible harms such as mental anguish and insult. ${ }^{173}$ Another rationale

167 See K. Redden, Punitive Damages 622 (1980).

168 Western Union Tel. Co. v. Guard, 283 Ky. 187, 197, 139 S.W.2d 722, 727 (1940) (quoting 15 AM. JuR. Damages $§ 65$ (1938)).

${ }_{169}$ See, e.g., Rieve v. McCormick, 11 Neb. 261, 264-65, 9 N.W. 88, 89 (1881) (noting that "[c]onstitutional guarantees of the rights of private property amount to but little if courts sanction its practical confiscation under the name of exemplary or punitive damages").

170 See K. REDDEN, supra note 167, at 24-25; see also Note, Exemplary Damages in the Law of Torts, 70 HARv. L. REv. 517, 518 (1957) (tracing the history of the doctrine of exemplary damages, which originated in eighteenth century England). Multiple damages actually predated punitive damages by several thousand years, as such awards were employed by the Code of Hammurabi in 2000 B.C. See K. REDDEN, supra note 167 , at 24 .

171 See K. Redden, supra note 167, at 26 (citing Huckle v. Money, 95 Eng. Rep. 768,769 (K.B. 1763), which involved an illegal trespass, assault, and false imprisonment by police upon entering a citizen's home).

${ }_{172}$ See id. at 26 (citing Earl v. Tupper, 45 Vt. 274, 275 (1873)).

173 See, e.g., Stuart v. Western Union Tel. Co., 66 Tex. 580, 584-85, 18 S.W. 351,354 (1885) (promoting compensation through punitive damages for harms such as mental suffering, which could not be measured in pecuniary terms); Fay v. Parker, 53 N.H. 342, 397 (1873) (justifying compensation through punitive damages for harms such as insult, which were not compensable at common law); Breadmore v. Carrington, 
holds that the differential treatment of similar offenses in civil and criminal law catalyzed the growth of punitive damages in civil cases. ${ }^{174}$

While a number of theories explain the evolution of punitive damages, today they are awarded in American jurisdictions to punish civil defendants for their acts and to deter both them and others from committing similar acts. ${ }^{175} \mathrm{~A}$ remedial scheme may now include a punitive damage award payable by a defendant who was found to have committed a "wilful, wanton, reckless, malicious, oppressive, or brutal act,"176 as well as compensation of victims of the wrongdoer's actions for their actual injuries. ${ }^{177}$ Punitive damages are part of the common law in most states, are codified for certain torts in some states, but are outlawed in four states. ${ }^{178}$ In most jurisdictions, proof of actual damages is a prerequisite to an award of punitive damages. ${ }^{179}$ In other jurisdic-

95 Eng. Rep. 790, 792-94 (K.B. 1764) (asserting that damages for intangible, personal torts such as slander and actions of imprisonment were not excessive).

${ }^{174}$ See Freifield, The Rationale of Punitive Damages, 1 OHIO S. L.J. 5, 9 (1935) (offenses to the person were punished much less severely in criminal law than were property offenses, giving rise to increased punishment for offenses to the person in civil suits).

175 See, e.g., Scott v. Donald, 165 U.S. 58, 63 (1897) (contending that the dispensary act of South Carolina is intended "to protect the public morals, public health and public safety"); Kirschbaum v. Lowrey, 165 Minn. 233, 236, 206 N.W. 171, 173 (1925) (clarifying that punitive or exemplary damages are awarded by a jury's discretion for punishing or deterring willful, malicious acts); Gostkowski v. Roman Catholic Church of the Sacred Hearts of Jesus and Mary, 262 N.Y. 320, 324, 186 N.E. 798, 800 (1933) (arguing that individuals who engage in willful and malicious disturbance of dead bodies must be punished both for their crimes and to deter others from committing similar acts); Gill v. Selling, 125 Or. 587, 591, 267 P. 812, 814 (1928) ("[p]unitive or vindictive damages are assessed on the theory of punishment and as a deterrent effect on others who might commit similar wrongs"). See generally W. Prosser \& W. KeETON, The LAW OF TORTS § 2 (1984) [hereinafter Prosser \& KeEtoN] (explaining that punitive damages are given in addition to the plaintiff's full compensation in order to punish the defendant and to deter both the defendant and others from future like acts).

$176 \mathrm{~K}$. REDDEN, supra note 167 , at 23 .

177 See C. McCormick, The Law of Damages $\S 77$ (1935); Prosser \& KeeTON, supra note $175, \S 2$.

${ }^{178}$ See Seltzer, supra note 147, at 44 \& n.39 (noting that Louisiana, Massachusetts, Nebraska, and Washington prohibit punitive damages and that states such as California, Colorado, and Georgia have codified the remedy for certain torts).

${ }^{179}$ See, e.g., PSG Co. v. Merrill Lynch, Inc., 417 F.2d 659, 663 (9th Cir. 1969), cert. denied, 397 U.S. 918 (1970) (punitive damages could not be recovered in light of the lack of evidence that appellant suffered any actual damages); James v. Public Fin. Corp., 47 Cal. App. 3d 995, 1000, 121 Cal. Rptr. 670, 673 (1975) (acknowledging the "well established rule . . that exemplary damages cannot ordinarily be assessed without a showing by the plaintiff as a prerequisite that he has sustained actual damages from defendant's wrongful act"); Village of Peck v. Denison, 92 Idaho 747, 751-52, 450 P.2d 310, 314-15 (1969) (requirement of actual damages before an award of punitive damages guarantees both that a legal interest has been violated and that punitive damages are not claimed without evidence of legal injury); Dicker v. Smith, 215 Kan. $212,216,523$ P.2d 371, 375 (1974) ("rationale of the rule requiring actual damages 
tions, however, courts may award punitive damages following proof of only "nominal" damages, that is, an infringement on the plaintiff's legal rights without the plaintiff suffering any actual harm. ${ }^{\mathbf{1 8 0}}$

Gontemporary criticisms of punitive damages abound. A focal point of attack has been the anomaly of a punitive remedy in civil law. One commentator has argued that punitive damages subject the defendant to a situation analogous to double jeopardy, because after punitive damages are awarded in a civil case, the defendant may also be punished in a criminal prosecution. ${ }^{181}$ This argument is consistent with a defendant's attempt to mitigate her liability in a civil trial by presenting proof of a previously paid criminal fine levied for the same act. ${ }^{182}$ In addition, the civil defendant facing punishment is afforded none of the procedural safeguards available to the criminal defendant, including a burden of proof requiring proof beyond a reasonable doubt and the privilege against self-incrimination. ${ }^{183}$

before punitive damages may be awarded is that we do not punish conduct, no matter how malicious or reprehensible, which in fact causes no injury"); Note, supra note 170, at 528-29 (general requirement of actual damages for punitive damages because a defendant cannot be punished only for wrongful conduct).

180 See, e.g., Maganini v. Coleman, 168 Conn. 362, 364, 362 A.2d 882, 883 (1975) (state law regards the infringement of rights as a nominal injury for which damages are required); Marshall v. Georgia Power Co., 134 Ga. App. 479, 480, 214 S.E.2d 728, 730 (1975) ("[n]ominal damages are always allowed for any invasion of a property right whether or not actual damages result therefrom"); Shell Oil Co. v. Parker, 265 Md. 631, 644, 291 A.2d 64, 71 (1972) (award of punitive damages in Maryland must be preceded by at least an award of nominal damages); Coonis v. Rogers, 429 S.W.2d 709, 716 (Mo. 1968) (punitive damages cannot be awarded unless actual or nominal damages are recovered); Mathis v. State Dep't of Roads, $178 \mathrm{Neb}$. 701, 707, 135 N.W.2d 17, 20 (1965) ("[n]ominal damages are those awarded, not as compensation for pecuniary loss, but in recognition of a legal wrong where there is no proof of actual damages"); Bryce v. Wilde, 39 A.D.2d 291, 293, 333 N.Y.S.2d 614, 616 (punitive damages may be awarded after an award of nominal compensatory damages and a showing of "actual malice" by the defendant), aff'd, 31 N.Y.2d 882, 292 N.E.2d 320, 340 N.Y.S.2d 320 (1972).

181 See Walther \& Plein, Punitive Damages: A Critical Analysis: Kink v. Combs, 49 MarQ. L. Rev. 369, 384 (1965).

182 See, e.g., Saunders v. Gilbert, 156 N.C. 463, 476, 72 S.E. 610,615 (1911) (recognizing the rule, "which we think is general, that when the defendant has been indicted and punished for the crime, the pecuniary punishment can be considered by the jury in reduction of punitive damages"); Smithwick v. Ward, 52 N.C. 64, 66 (1859) (evidence may be admitted at trial that the defendant has been convicted and punished in order to mitigate punitive damages for the same transaction); Wirsing v. Smith, 222 $\mathrm{Pa} .8,16,70 \mathrm{~A}$. 906, 909 (1908) (jury may consider evidence of a defendant's conviction and sentence for his crime in mitigation of punitive damages).

${ }_{183}$ See, e.g., Morris v. MacNab, 25 N.J. 271, 281, 135 A.2d 657, 663 (1957) ("inclusion of punitive damages in the plaintiff"s tort judgment, which is allowable for the private wrong to the individual rather than the accompanying wrong to the public, may effectively supplement the criminal law in punishing the defendant"); Pratt v. Duck, 28 Tenn. App. 502, 507, 191 S.W.2d 562, 564 (1945) (criminal punishment for an act does not exempt liability for punitive damages for the same act); see also Al- 
Punishment for criminal acts, moreover, consists of fines and finite sentences set by a legislature. Civil punishment departs considerably from these limits because the trier of fact has complete discretion over the amount of the award and, consequently, bases its decision on subjective observations at trial. This approach may lead to awards that do not accurately reflect the seriousness of the defendant's behavior. ${ }^{184} \mathrm{Ex}-$ acerbating this problem is the fact that punitive damages for similar acts are inconsistent within and across jurisdictions. ${ }^{185}$ Judicial review of such awards for "impropriety of motive or gross disproportion" has not produced the consistency of punishment found in the criminal law. ${ }^{186}$

Defendants also have challenged punitive damages on constitutional grounds. They have argued that the imposition of penal sanctions, albeit in a civil adjudication, is unconstitutional whenever defendants are not afforded the protection of the fourth, fifth, and sixth amendments. ${ }^{187}$ Punitive damages, moreover, may constitute a violation of the notice aspect of due process. Criminal statutes provide notice to potential criminal defendants as to what types of behavior are unlawful and as to what penalties will accompany convictions. Givil defendants, in contrast, have notice neither as to what sort of behavior is egregious enough for punishment nor as to what their punishment will be once liability is established. ${ }^{188}$ As one commentator points out, "[p]unitive damages are assessed for 'wanton, wilful, or malicious conduct,' which are hardly specific criteria."188

dridge, The Indiana Doctrine of Exemplary Damages and Double Jeopardy, 20 InD. L.J. 123, 136 (1945) (Indiana case law has supported the proposition that the legislature is not empowered to grant punitive damages when the defendant is open to criminal prosecution for the same act.); Note, The Imposition of Punishment by Civil Courts: A Reappraisal of Punitive Damages, 41 N.Y.U. L. REv. 1158, 1184 (1966) (implementation of punitive damages appears to be unjustified when the criminal law is in operation although it may be "a useful substitute for criminal law in areas where criminal punishment is inappropriate").

184 See Walther \& Plein, supra note 181 , at 383-86.

188 See K. REDDEN, supra note 167, at 38. Criminal punishment, though, is arguably inconsistent as well. See Robinson, A Sentencing System for the 21 st Century?, 66 TEX. L. REv. 1, 8-10 (discussing the goal of uniform sentencing in the sentencing guidelines recently promulgated by the United States Sentencing Commission).

${ }_{186}$ See McCormick, Some Phases of the Doctrine of Exemplary Damages, 8 N.G.L. REv. 129, 130 (1930).

${ }_{187}$ See, e.g., Rex Trailer Co. v. United States, 350 U.S. 148, 150-51 (1956) (issue dismissed); United States ex rel. Marcus v. Hess, 317 U.S. 537, 548-49 (1943) (same); Missouri Pac. Ry, v. Humes, 115 U.S. 512, 523 (1885) (same); see also Herald Co. v. Harper, 293 F. Supp. 1101, 1105 (E.D. Mo. 1968), affd, 410 F.2d 125, 131 (8th Cir. 1969) (issue was given further consideration but ultimately dismissed).

${ }_{188}$ See K. REDDEN, supra note 167, at 610-11.

189 Id. at 611 . A final constitutional argument against punitive damages criticizes the "chilling effect" such awards have on the free speech of defendants in defamation 
Another attack on punitive damages questions the rationale behind transferring monies from the defendant to the plaintiff in the name of an exemplary award. Some commentators have labeled them "unjust enrichment" or overcompensation of plaintiffs. ${ }^{190}$ They argue that these awards should be distributed to society-the entity actually punishing the defendant. ${ }^{191}$ These "windfalls" may encourage not only embellished complaints, but also frivolous litigation. ${ }^{192}$ This sort of litigation is facilitated by both a plaintiff's opportunity to present evidence of a defendant's "deep pocket" at trial and contingent fee representation. ${ }^{183}$

The most prominent criticism of punitive awards concerns their escalating size. One cause of this increase is arguably the institutional incompetence inherent in the tort process. While juries are wellequipped to assess the magnitude of compensation needed to make a victim whole, they simply lack the expertise to determine the size of a penal award that will effectively punish and deter a defendant whose behavior can only be understood with specialized knowledge. ${ }^{104} \mathrm{Al}$ though the trier of fact's wide discretion over penal damages is limited somewhat by the requirement that such awards bear a reasonable relationship to compensatory damages, it is questionable whether this relationship exists. ${ }^{195}$ For example, in Smith v. American Family Mutual Insurance Co., ${ }^{196}$ the plaintiff sued for tortious breach of an implied covenant of good faith and fair dealing in the context of an automobile liability insurance contract. The court held that a compensatory award of $\$ 3,000$ did not inherently render a punitive award of $\$ 50,000$ excessive. ${ }^{197}$ And while compensatory damages are based on the actual in-

actions. See Note, Punitive Damages in Defamation Litigation: A Clear and Present Danger to Freedom of Speech, 64 YALE L.J. 610, 613 (1955).

190 See, e.g., C. MCCormICK, supra note $177, \S 78$ (punitive damages are unjustifiable because actual damages already make plaintiff whole); Long, Punitive Damages: An Unsettled Doctrine, 25 Drake L. Rev. 870, 886 (1976) (if punitive damages are intended to punish on behalf of society, then they should be paid to society rather than an individual).

101 See Long, supra note 190 , at 886-87.

182 See Prosser \& KeEton, supra note $175, \S 2$ (discussing frivolous litigation); C. McCormick, supra note $177, \S 78$ (noting how such windfalls encourage the pursuit of claims that otherwise would be economically unattractive).

193 See K. REDDEN, supra note 167, at 628-29.

194 See id. at 39. Obviously, some tort claims are resolved with bench trials, but it is not clear that judges have any more expertise in assessing a defendant's behavior than lay juries.

${ }_{105}$ See Duffy, Punitive Damages: A Doctrine Which Should Be Abolished, in The Defense Research Inst., The Case Against Punitive Damages 12 (1969) (citing cases in which punitive damages bear no rational relationship to compensatory damages).

196294 N.W.2d 751 (N.D. 1980).

$187 \mathrm{See}$ id. at 767. Other recent examples of "nonexcessive" punitive damage awards are found in Puz v. McDonald, 140 Ariz. 77, 79, 680 P.2d 213, 215 (Ariz. Ct. 
jury suffered and thus are easily reviewed, the same cannot be said of a punitive award. Indeed, an appellate court reviewing a punitive award has no record of how the trier of fact determined that the punitive damages awarded were sufficient to punish and deter the defendant. ${ }^{198}$

Finally, considerable controversy surrounds the imposition of punitive damages in mass tort litigation. Multiple defendant suits, it is urged, result in awards that may be appropriate for one defendant but clearly excessive for others. ${ }^{199}$ This occurs because while juries "theoretically can gauge the financial status of each defendant and assess an award sufficient to punish but not overwhelm any defendant, juries are not wont to act with such finesse. The awards are almost certain to hurt some defendants unduly if they hurt others enough."200 Punishment, therefore, is unreasonably harsh for the latter defendants, although deterrence still may be achieved. The multiple plaintiff scenario also presents problems. Mass tort cases for which a class of plaintiffs has not or cannot be certified involve a number of different suits, each with the potential for large punitive awards. Defendants finding them-

App. 1984) $(\$ 40,000$ for emotional distress, outrage, and anxiety did not preclude an award of $\$ 200,000$ punitive damages); Robinson v. Winn-Dixie Stores, 447 So. 2d 1003 , 1005 (Fla. Dist. Ct. App. 1984) (upholding $\$ 750,000$ award of punitive damages against a multimillion dollar corporation that erroneously charged a customer with shoplifting), affd in part and quashed in part, 472 So.2d 722, 725 (Fla. 1985) (affirming district court's reversal of trial court's directed verdict against punitive damages, and remanding pursuant to alternative order granting new trial on issue of punitive damages); Auburn Harpswell Ass'n v. Day, 438 A.2d 234, 237 (Me. 1981) (upholding $\$ 50$ award for actual damages and $\$ 3,000$ for punitive damages for chopping down a tree); see also Massey, The Excessive Fines Clause and Punitive Damages: Some Lessons from History, 40 VAND. L. REV. 1233, 1271-74 \& n.233 (urging the incorporation of the excessive fines clause into the fourteenth amendment to limit state-awarded punitive damages such as the $\$ 3$ billion exemplary fine imposed on Texaco in Pennzoil Co. v. Texaco, Inc., 107 S. Ct. 1519 (1987)).

The United States Attorney General recently established a Tort Policy Working Group that examined tort awards in the context of the crisis in liability insurance. See RePort of THE TORT POLICY Working Group on the Causes, Extent and Policy Implications of the CurRent CRISIs in INSURance Availability aND AFFORDABILITY (1986) [hereinafter REPORT]. The Report indicates that the average product liability jury verdict increased from $\$ 393,850$ to $\$ 1,850,452$ during the period 1975 to 1985 . See id. at 36 . This increase, though, is skewed by the sharp jump in million-dollar or greater verdicts. See id. at 39. Nonetheless, the Report points out that the growth of noneconomic damages such as punitive damages have "play[ed] a major role in the explosive growth of large verdicts ...." Id. The study then provides data from Cook County, Ill., demonstrating that the average punitive damage award jumped from $\$ 63,000$ in $1970-74$ to $\$ 489,000$ in $1980-84$, far outstripping inflation in those years. See $i d$. at $39-42$.

198 See K. REDDEN, supra note 167 , at 43.

${ }^{199}$ See Long, supra note 190 , at 885 ; see also D. DobBs, HANDBOOK ON THE LAW of REMEDIES $\S 3.9$ (1973) (Although no consistent rule exists in mass disaster litigation, in some courts a culpable defendant will escape civil liability that would have been imposed in the case of a single plaintiff.).

200 See Long, supra note 190 , at 885. 
selves in this situation may be subjected to repeated punishment for a single act. ${ }^{201}$ Additionally, plaintiffs suing first in time and receiving compensatory and punitive damage awards may exhaust their defendants' wealth to such a degree that later plaintiffs stand little chance of collecting on subsequent awards. ${ }^{202}$ The potential also exists for plaintiffs in different jurisdictions to receive radically different punitive damage awards based on the same set of facts. ${ }^{203}$

The contemporary arguments against punitive damages apply with added force in the Wilson or Ferebee contexts. An exemplary award exposes Chevron to a position akin to double jeopardy, because not only can it be punished through civil damages, but it may also be subject to criminal prosecution if it has violated FIFRA. Chevron faces jury fines, moreover, without any of the constitutional safeguards afforded defendants in criminal prosecutions for the same acts. If punitive awards are not instructive and consistent, which is quite possible given the expertise required for labeling pesticides, then Chevron arguably has not been given the notice required by due process in the criminal context. Furthermore, the jury that Chevron may face at trial will have wide discretion over a scientific matter in which it lacks expertise. Nor will the jury be bound to follow the intent of Congress or the cost-benefit mode of decisionmaking that Congress authorized the EPA to use. Finally, if OPGL causes multiple plaintiff litigation that is not procedurally consolidated, the imposition of large punitive damage awards against Chevron by early plaintiffs may leave later litigants undercom-

201 See Prosser \& KeEToN, supra note $175, \S 2$. Generally, a defendant also may introduce evidence of other actions against her when the plaintiff seeks a punitive award. See Roginsky v. Richardson-Merrill, Inc., 378 F.2d 832, 838-39 (2d Cir. 1967) (reversing punitive damages award in products liability action against manufacturer of anti-cholesterol drug). In Roginsky, Judge Friendly had difficulty seeing "what even the most intelligent jury would do" with such attempts to reduce excessive awards. Id. at 839 .

${ }^{202}$ See D. DoBbs, supra note $199, \S 3.9$; K. REDDEN, supra note 167 , at 118. Generally, however, a defendant may introduce evidence of her financial resources when punitive damages are sought. Id. at 122 . Note, however, that recent attempts to obtain certification of a class of plaintiffs under Rule 23 of the Federal Rules of Civil Procedure by arguing that earlier plaintiffs would exhaust the defendant's assets have failed. See, e.g., In re School Asbestos Litigation, 789 F.2d 996, 1002-08 (3d Cir.), cert. denied, 107 S. Ct. 182, 318 (1986).

${ }^{203}$ Such results were apparent in the hundreds of suits filed against RichardsonMerrill Inc. over the drug MER/29. For example, the Roginsky trial verdict awarded $\$ 17,500$ in compensatory damages and $\$ 100,000$ in punitive damages to the plaintiff. See Roginsky, 378 F.2d at 834. The plaintiff in Toole v. Richardson-Merrill, Inc., 251 Cal. App. 2d 689, 60 Cal. Rptr. 398 (1967), who also developed cataracts in connection with using MER/29, was awarded $\$ 175,000$ in compensatory damages and $\$ 500,000$ in punitive damages. The plaintiff allowed the punitive damages to be halved in order to avoid a new trial on the issue of those damages. See id. at 693-94, $60 \mathrm{Cal}$. Rptr. at 403. 
pensated, thus undermining the state goal of compensating tort victims.

\section{The Conflict Between Punitive Damages and FIFRA}

The evolution and function of punitive damages in tort law thus indicates that the remedy directs or regulates behavior by delineating a standard of conduct that is tortious, and by deterring the defendant and others from engaging in such conduct. ${ }^{204}$ These characteristics, however, were largely ignored by the District of Columbia Gircuit in.Ferebee and by the Wilson court when it relied on the circuit court's analysis. The Ferebee court prefaced its remarks on a conflict with state tort law by conceding that "[d]amage actions, typically, . . . can have both regulatory and compensatory aims." 205 The court then explained the variety of effects these awards will have on manufacturer defendants:

The verdict itself does not command Chevron to alter its label-the verdict merely tells Chevron that, if it chooses to continue selling paraquat in Maryland, it may have to compensate for some of the resulting injuries. That may in some sense impose a burden on the sale of paraquat in Maryland, but it is not equivalent to a direct regulatory command that Chevron change its label. Chevron can comply with both federal and state law by continuing to use the EPA-approved label and by simultaneously paying damages to successful tort plaintiffs such as Mr. Ferebee.

Moreover, tort recovery in a case such as this one may also promote legitimate regulatory aims. . . . Successful actions of this sort may lead manufacturers to petition [the] EPA to allow more detailed labelling of their products . . . . In addition, the specter of damage actions may provide manufacturers with added dynamic incentives to continue to keep abreast of all possible injuries stemming from use of their product so as to forestall such actions through product improvement. $^{208}$

The decision never clarifies exactly how or why such a damage award

204 See S. Shavelu, Economic ANalysis of Accident Law 277-86 (1987) (arguing that tort liability and statutes are different forms of regulation); Note, supra note 183, at 1158-59 (stating that "punitive damages attempt[] to achieve, through civil litigation, results otherwise associated with the criminal law"); Silkwood Analysis, supra note 17, at 703, 709 (discussing the regulatory purpose of punitive damages).

${ }^{205}$ Ferebee, 736 F.2d at 1540.

${ }^{208}$ Id. at 1541-42. 
will not "command" Chevron to change its label, yet still have a "regulatory effect" by encouraging petitions to the EPA and promoting information-gathering on pesticide injuries. The confusion may arise from the fact that the Ferebee court was only reviewing the compensatory damages of $\$ 60,000$ that were awarded at trial. ${ }^{207}$ In addition to the reparative function of such awards, they can have an incidental regulatory impact. ${ }^{208}$ Inasmuch as compensatory damages are nonregulatory, however, Ferebee has little application to the preemption of punitive damages. ${ }^{200}$

To the extent that compensatory damages encourage or elicit behavior from defendants, ${ }^{210}$ though, the Ferebee analysis sheds light on the preemption problem. Significantly, the behavior that the court predicted a damage award would promote is the identical behavior that FIFRA and the EPA already require. ${ }^{211}$ Thus, the imposition of exemplary fines on a defendant who was in compliance with FIFRA ${ }^{212}$ establishes another standard of testing, information-gathering, and labeling than is demanded by FIFRA. This conflicts with the functioning of the federal law as manufacturers are torn by two different behavioral directives. ${ }^{213}$ Punitive fines also conflict with the objectives of FIFRA, which seek safe labeling as defined by EPA expertise. As Justice Blackmun argued in his dissent in Silkwood v. Kerr-McGee Corp. ${ }^{214}$ a federally preeminent statute and exemplary awards cannot coexist:

Were [the defendant] to continue adherence only to the federal standard, it would presumably be in continuous violation of state. law-an indication that the jury award in this 1982)

${ }^{207}$ See Ferebee v. Chevron Chem. Co., 552 F. Supp. 1293, 1297 \& n.17 (D.D.C.

208 See K. REDDEN, supra note 167, at 40.

209 The Wilson court recognized this dilemma. See Wilson, slip. op. at 13-14.

210 Note that punitive damages can have a partial compensatory effect. See Long, supra note 190, at 875-76; Owen, Punitive Damages in Products Liability Litigation, 74 MICH. L. REv. 1257, 1295-99 (1976); Walther \& Plein, supra note 181, at 381-82; Note, supra note 183 , at 1162-63.

${ }_{211}$ See supra notes $21-32$ and accompanying text.

212 See Wilson, slip. op. at 4 ("Chevron has at all times complied with FIFRA and EPA regulations regarding the labelling and registration of OPCL."); Ferebee, 552 F. Supp. at $1304 \&$ n.38 (jury was correctly instructed that it could consider Chevron's compliance as a fact "in deciding whether the label is adequate"); see also Silkwood Analysis, supra note 17, at 713 (noting Chevron's compliance with FIFRA in Ferebee).

${ }_{213}$ The Third Gircuit recognized this issue in Cipollone v. Liggett Group, Inc., 789 F.2d 181 (3d Cir. 1986), cert. denied, 107 S. Ct. 907 (1987), when it did not use the Ferebee "physical conflict" analysis. See id. at 186-88; see also supra text accompanying notes 107-1l (distinguishing the conflict analysis in Cipollone from the analysis used in Ferebee and Silkwood).

214464 U.S. 238 (1984). 
case was too small to serve its purpose. A [defendant] that continues to meet only the federal standard therefore presumably will receive increasingly large punitive sanctions in subsequent personal injury suits, until compliance with the state-imposed safety standard is obtained. At that point, of course, the federal safety standard will have been entirely supplanted. It is incredible to suggest that Congress intended the Federal Government to have the sole authority to set safety regulations, but left intact the authority of States to require adherence to a different state standard through the imposition of jury fines. The obvious conflict shows that punitive damages are pre-empted. ${ }^{\mathbf{2 1 5}}$

It might be argued, nonetheless, that state and federal laws do not conflict because FIFRA merely provides a floor or minimum of labeling safety above which states may impose stricter standards. ${ }^{216}$ It would not be impossible, therefore, for manufacturers to comply with both standards if they comply with the more strict state standard of pesticide labeling. Indeed, this argument is quite plausible in the context of the local regulation of the registration of pesticides, because FIFRA provides that states may enact EPA-approved regulations concerning registration that are stricter than EPA standards. ${ }^{217}$ Congress, however, did not contemplate a scheme of labeling regulation that allowed state standards to coexist, let alone vary above a federal minimum. This is evidenced by the fact that no provision for stricter state labeling standards was inserted into FIFRA, as it was for registration. The language of the statute supports this reading of congressional intent, as it prohibits states from "impos[ing] or continu[ing] in effect any requirements for labeling or packaging in addition to or different from those required [by FIFRA]."218 FIFRA prohibits any labeling that varies above or

225 Id. at 265 (Blackmun, J., dissenting).

${ }^{218}$ See Comment, Preemption Doctrine in the Environmental Context: A Unified Method of Analysis, 127 U. PA. L. Rev. 197, 212-13 (1978) (proposing that preemption questions in the environmental law context be analyzed with a presumption that federal law provides minimum regulatory standards above which the states may create stricter regulations); cf. Note, Getting Away with Murder: Federal OSHA Preemption of State Criminal Prosecutions for Industrial Accidents, 101 HARv. L. REv. 535, 545 (1987) (discussing "nationwide floor of effective safety and health standards" created by OSHA that do not conflict with local criminal prosecutions of employer conduct).

${ }^{217}$ See 7 U.S.C. \& 136v(c) (1982). This has been recognized by the courts. See, e.g., National Agric. Chem. Ass'n v, Rominger, 500 F. Supp. 465, 469-70 (E.D. Cal. 1980) (refusing to preempt state registration standards that varied above federal minimum and contrasting the legislative history of federal registration and labeling).

${ }^{218} 7$ U.S.C. § 136v(b) (1982) (emphasis added). 
below the labeling standards developed and approved by the EPA. ${ }^{\mathbf{2 1 0}}$ Thus, any state regulation of labeling that differs from FIFRA will yield zero-sum results: When a manufacturer complies with a different state labeling requirement, it necessarily violates FIFRA. ${ }^{220}$

\section{B. An Economic Analysis of the Conflict Between Preemption and Punitive Damages under FIFRA}

On occasion, this Comment has implicitly used economic theory to analyze the preemption dilemma. For example, in examining the importance of uniformity within the occupation test of preemption, this Comment analyzed the incentives and responses of manufacturers and consumers to nonuniform labeling to argue in favor of preemption..$^{221}$ The conflict with state law test, which requires an analysis of the coexistence of punitive damages and a comprehensive federal law, provides particularly fertile ground for an economic analysis of the Wilson and Ferebee scenarios. ${ }^{222}$ Although a comprehensive economic analysis of the coexistence of FIFRA and punitive damages is beyond the scope of this Comment, a brief look at the issues that such an approach raises is provided because it highlights the conflicts created by this juxtaposition. The touchstone of this analysis will be the conclusion by the Ferebee court, upon which the Wilson decision relied, that there is no conflict

218 See Chemical Specialties Mfrs. Ass'n v. Lowery, 452 F.2d 431, 439 (2d Cir. 1971) (noting that more stringent New York Gity labeling requirements for aerosol pesticides "would, in fact, be inconsistent with FIFRA regulations rather than supplemental. Indeed, it could be contended that the conflict between local and federal requirements is most significant where federal law would require no special label and the City Regulations would.").

220 Obviously, a state labeling requirement that is less strict than FIFRA will put a complying manufacturer in violation of FIFRA. When a state labeling directive is identical to FIFRA, a manufacturer may then be in compliance with both simultaneously. Cf. Capital Cities Cable, Inc. v. Grisp, 467 U.S. 691 (1984) (federal regulation prohibiting cable television operators from deleting out-of-state signals preempts a state law punishing cable operators who did not delete the signals).

${ }_{221}$ The examination of incentives to behavior is classic economic analysis. See $\mathrm{W}$. Landes \& R. Posner, The Economic Structure of Tort Law (1987); A. PoLINSKY, AN INTRODUCTION TO LAW AND ECONOMICS (1983); R. POSNER, ECONOMIC ANALYSIS OF LAW (3d ed. 1986); Braithwaite, The Limits of Economism in Controlling Harmful Corporate Conduct, in REAdINGS IN THE ECONOMICS OF LAW AND REgULATION 258 (1984).

${ }^{222}$ A number of commentators have analyzed the economics of punitive damages in great detail. See, e.g., Cooter, Economic Analysis of Punitive Damages, 56 S. CAL. L. REv. 79 (1982); Ellis, Fairness and Efficiency in the Law of Punitive Damages, 56 S. CaL. L. Rev. 1 (1982); Owen, Problems in Assessing Punitive Damages Against Manufacturers of Defective Products, 49 U. CHI. L. REv. 1 (1982); Priest, Punitive Damages and Enterprise Liability, 56 S. CAL. L. REv. 123 (1982); Schwartz, Deterrence and Punishment in the Common Law of Punitive Damages: A Comment, 56 S. CaL. L. Rev. 133 (1982). 
between paying punitive fines and complying with a comprehensive federal regulatory and punitive scheme. ${ }^{223}$

The Ferebee court's refusal to acknowledge such a conflict is predicated on the court's prediction of Chevron's reaction to the potential coexistence of punitive damages defining egregious labeling behavior and FIFRA's regulation of labeling. The availability of punitive damages, however, will create a new mix of costs that may encourage quite different behavior on the part of Chevron and similar manufacturers. Consider the following possible instances of double regulation that Chevron may encounter. First, Chevron could face a state award of punitive damages that delineates a less strict standard of appropriate labeling behavior than FIFRA. Second, punitive damages might command behavior that is more cautious than the requirements of FIFRA. Finally, an exemplary award might replicate the provisions for labeling in FIFRA.

As argued earlier, if a manufacturer in the first two scenarios above gears its labeling to state law, it will violate FIFRA. ${ }^{224}$ The manufacturer will thereby avoid the often large cost of paying punitive damages. ${ }^{225}$ However, it will incur the costs of discovering state labeling requirements through interim punitive damage awards, which may change over time depending on new jury verdicts, and the expense of changing labels accordingly. In addition, it will face the costs associated with a violation of FIFRA, such as civil fines and the expenses of defending against a civil or criminal action by the Attorney General. There are, moreover, opportunity costs associated with spending time and money on such a defense. Alternatively, if a manufacturer chooses to comply with FIFRA, it will incur the highly speculative and potentially huge cost of paying punitive damages to tort plaintiffs, as well as the costs of civil litigation. ${ }^{226}$ There are opportunity costs for spending money in this manner as well. Although this choice avoids the cost of noncompliance with FIFRA, the manufacturer will still face the static cost of compliance arising from testing, monitoring of products, and interacting with the EPA. Finally, the third possible scenario would allow a manufacturer to avoid or incur the costs of noncompliance with

${ }^{223}$ See Ferebee, 736 F.2d at 1540-42; Wilson, slip op. at 13; see also Silkwood, 464 U.S. at 257 ("Paying both federal fines and state-imposed punitive damages for the same incident would not appear to be physically impossible.").

224 See supra notes 216-20 and accompanying text.

225 See supra notes $194-98$ and accompanying text.

${ }^{226}$ Litigation expenses can be a very significant proportion of a defendant manufacturer's expenses. For example, 62 cents of every dollar paid out by asbestos manufacturers and their insurers went to attorneys' fees and litigation expenses. See REPORT, supra note 197, at 42 . 
both regulations, as well as avoid or incur the costs arising from compliance with double regulation.

Although no attempt is made here to quantify exact costs, ${ }^{227}$ it is reasonable to predict that when faced with different state and federal standards of labeling, noncompliance with FIFRA and compliance with state labeling standards could become the less costly, more attractive alternative. At the very least, the costs associated with the Ferebee scenario of stricter state labeling standards divert attention from and discourage compliance with EPA-developed labels and testing requirements. Discouraging compliance with federal law, of course, was grounds for preemption under the Court decisions that favor the doctrine. ${ }^{228}$ In any case, the coexistence of state and federal labeling requirements creates a conflict that Congress never intended to exist. Even assuming, as the Ferebee court does, that Chevron will then petition the EPA for a new label in the hope of bringing state and federal standards closer together, there is likely to be a considerable time lag before the petition, if approved, will result in a new label. ${ }^{228}$ This leaves defendants choosing between two labeling standards as they await EPA approval and as new suits defining new labeling standards arise. It is also unclear how the EPA will respond to a number of different petitions that reflect labeling standards developed by as many different states. If state and federal standards converge, as the third scenario suggests, it is less easy to predict how a manufacturer will respond to the costs of not complying with both. Certainly, compliance with one would be less costly than compliance with two, which is the situation that preemption of punitive damages would bring about.

Whether or not a corporate defendant actually bears the tort award costs directly, as the Ferebee court suggests it will, also is far

227 The data available on the cost of compliance is not translated into values that are comparable to the cost of punitive damages mentioned earlier. An appropriate comparison might juxtapose the annual costs of OPCL's compliance with FIFRA with the annual costs of OPCL-related punitive damages and litigation. The following facts, though, give a rough sense of what those compliance costs might be. In 1981, the average research and development cost of registering a pesticide under FIFRA was approximately $\$ 6.9$ million dollars. See Davies, The Effects of Federal Regulation on Chemical Industry Innovation, LAw \& CONTEMP. PROBS., Summer 1983, at 41, 51. "Of the $\$ 450$ million total pesticide industry research and development expenditures in 1981, $67 \%$ was devoted to development of new products, $25 \%$ to product expansion, and $8 \%$ to registration and product defense." Id. Data for 1980 reveals that 34 companies spent $\$ 38$ million dollars on reregistration and product defense of all their pesticides. See Hoerger, Beamer \& Hanson, The Cumulative Impact of Health, Environmental, and Safety Concerns on the Chemical Industry During the Seventies, LAw \& ConTeMP. Probs., Summer 1983, at 57, 95 (table 24).

${ }^{228}$ See supra notes 86-90 and accompanying text.

229 It takes approximately two years to register a pesticide with the EPA. See Davies, supra note 227 , at 52 . 
from clear. The manufacturer may respond to the award by passing on its increased costs to consumers via raising its prices. ${ }^{230}$ Thus, instead of defendants bearing tort award costs directly, consumers would actually fund tort damages awarded to victims. Although insurance for punitive damages is prohibited in a few states, ${ }^{231}$ a manufacturer with insurance could fund such damages with its policy and pass on the costs of premiums to consumers. The recent trend toward unusually large tort awards and the possibility of multiple claimants, however, may induce more serious reactions from Chevron. Tort awards could reach, and some say have already reached, what Judge Friendly termed "catastrophic amounts,',232 making a defendant's financial collapse a realistic possibility. To be sure, the probability that one punitive damage award could cause a company like Chevron to collapse is low; however, that probability increases as the number of awards increase or as the amount of the defendant's liability insurance decreases. ${ }^{\mathbf{2 3 3}}$

One commentator has assessed a range of alternative strategic reactions of a corporation to mass tort liability. ${ }^{234}$ As a protective measure, a corporation could set up a separate subsidiary to sell its more dangerous products, and thereby minimize the risk of liability "overwhelming the entire firm."2ss This might be followed by a sale of the subsidiary to shareholders to further reduce exposure to potential liability. ${ }^{236}$ Another response would entail a "strategic liquidation of the firm," which would require that the firm operate just outside of bankruptcy and "consign it[self] to a slow, bleeding, perhaps decades-long rundown." ${ }^{287}$ Finally, the corporation might pursue a mass tort bankruptcy reorganization that makes tort claimants substantial owners of the firm. ${ }^{238}$

2so See Roginsky v. Richardson-Merrill, Inc., 378 F.2d 832, 841 (2d Cir. 1967). It should be noted that in a competitive market, it is unlikely that a manufacturer could pass all these costs onto its consumers and still maintain its competitive market position. Chevron, however, has a near monopoly in the production and sale of OPGL in the United States, see supra text following note 36, making it more likely that it will be able to pass such costs on to consumers.

231 See Seltzer, supra note 147, at 51 n.76.

232 Roginsky, 378 F.2d at 841.

233 The resulting failure of the business enterprise seems to be a needless, unwarranted consequence of the litigation. See id. It is quite unfair to stockholders, moreover, who "suffer[] extinction of their investments for a single management sin." Id. Indeed, much like consumers, stockholders also could end up funding tort awards and being punished for management's misdeeds. (1986).

${ }^{234}$ See Roe, Corporate Strategic Reaction to Mass Tort, 72 VA. L. REv. 1

${ }^{235}$ Id. at 4-5.

${ }^{236} \mathrm{See} i d$. at 5.

237 Id.

${ }^{233}$ See id. at 6. Several corporations have filed for bankruptcy in the past under 
The punitive costs stemming from the distribution of one product, such as OPCL, could have ramifications for the manufacture of other products as well. As the size of individual tort awards increases and as claims multiply, Chevron will have to incorporate these costs into the feasibility projection of a new product. In light of these added costs, other costs associated with the new product must be cut if the profit margin is to remain the same. ${ }^{23 \theta}$ Chevron might choose to cut back on some of the testing required by the EPA or at least the additional testing Chevron conducts over and above FIFRA requirements. Such cost constraints might even deter Ghevron from launching the product at all, ${ }^{240}$ thereby depriving the consuming public of a potentially useful product.

The exact magnitude of Chevron's response to the scenario created by the Ferebee decision, of course, is very difficult to forecast. Much may depend on how efficient Chevron is at cost avoidance. ${ }^{241}$ The less efficient Chevron is at avoiding or absorbing the costs of punitive damage awards, the more dramatic will be its reaction to these awards; this, in turn, suggests that serious conflicts with FIFRA could arise. Moreover, the gravity of these conflicts may depend on the market for OPCL. Assume, for example, that other manufacturers eventually develop substitute pesticides and this variety of products creates a relatively elastic demand for any particular pesticide. If Chevron responds to punitive damages by passing such costs on to consumers, the price increase associated with its pesticide will cause buyers to switch from Chevron's pesticide to that of another manufacturer. ${ }^{242}$ Chevron, therefore, will be unable to pass on these additional costs to its consumers and will directly bear the cost of paying multiple exemplary awards.

The seriousness of Chevron's reaction also may depend on the

these circumstances, including several asbestos manufacturers. See Roe, Bankruptcy and Mass Tort, 84 Colum. L. Rev. 846, 847 n.5 (1984).

239 See Davies, supra note 227, at 52 ("For a large firm deciding whether to market a major new product, the direct regulatory costs are unlikely to significantly influence the decision. Data obtained from one large company on typical costs for developing a new pesticide indicate that the added regulatory costs of $\$ 1$ million would not significantly influence the decision to market the pesticide. On the other hand, for a firm deciding whether to make a single small-volume batch of a new chemical, at cost of maybe $\$ 10,000$ to $\$ 30,000$, almost any regulatory costs may influence the decision to proceed." (footnote omitted)).

240 See McKean, Product Liability: Implications of Some Changing Property Rights, in Readings in the Economic ANALYSIS of LAW aNd Regulation, supra note 221 , at 127,131 .

241 See W. Landes \& R. Posner, supra note 221, at 120.

${ }^{242}$ Currently, though, Chevron has monopoly control over pesticide pricing. See supra note 230 . 
amount of risk that is associated with its costs. ${ }^{243}$ Assume that Chevron is risk-averse and that insurance has not mitigated this aversion significantly. Contemporary empirical evidence suggests that companies like Ghevron face the risk of paying very large punitive damages in failureto-warn tort cases. ${ }^{24}$ The exact size of these awards is also an everchanging variable. Although the trier of fact's discretion over an award of punitive damages is limited by the requirement that the award exhibit a reasonable relationship to the actual damages sustained by a victim, recent history indicates that no such relationship exists. ${ }^{245}$ The size of the award is particularly uncertain, moreover, in that it is based on the trier of fact's subjective view of the egregiousness of the defendant's behavior. Because the risk of a large punitive damage award is high, and the potential size of that award indeterminable, the impact of the state's regulatory directive through jury fines will be exacerbated. At the very least, economic analysis suggests that unpredictable, large state tort awards provide risk-averse manufacturers with a notable disincentive to comply with federal standards. Thus, the granting of these awards conflicts with the objectives and functioning of FIFRA.

\section{Judicial and Legislative Responses to Conflicting Regulation of Pesticide Labeling}

The problems created by the coexistence of FIFRA's regulatory scheme and the award of punitive damages in failure-to-warn tort cases call for either a judicial or legislative solution. The occupation analysis offered in this Comment indicates that the appropriate judicial response to these problems is preemption, a response supported by the fact that Congress explicitly and implicitly intended to control the regulation of pesticide labeling. The conflicts that exist between FIFRA and punitive damage awards also militate in favor of preemption. The regulatory nature of exemplary awards conflicts with FIFRA's regulatory scheme, creating tensions that make it difficult and inefficient for manufacturers to pay punitive awards and comply with FIFRA simultaneously. Importantly, preemption of punitive damage awards would still preserve a claimant's ability to obtain compensation, thus preserving the states'

${ }^{243}$ See generally A. Polinsky, supra note 221, at 51-56 (discussing risk bearing and insurance).

${ }^{244}$ See supra notes 194-98 and accompanying text; see also Dworkin, Federal Reform of Product Liability Law, 57 TuL. L. Rev. 602, 602-606, 615 (1983) (noting that jury awards, including punitive damage awards, have increased in products liability cases more than in any other area of the law).

${ }^{245}$ See Owen, Punitive Damages in Products Liability Litigation, $74 \mathrm{MICH}$. L. REv. 1258, 1320 (1976) (noting the risk that a jury will overpunish a manufacturer through punitive damage awards). 
ability to compensate tort victims--a function that is traditionally left to local control.

Judicial preemption should be supplemented with several legislative responses. Congress should amend FIFRA to provide a more explicit delineation of federal and state regulatory responsibilities. ${ }^{248}$ The state functions listed under Sections 24(a) and 24(c) of the statute should be more clearly distinguished from the federal labeling responsibilities set forth in Section 24(b) with an explicit prohibition of state regulatory activities that have the effect of creating labeling requirements. This amendment will strengthen motions to preempt punitive damages such as those made by Chevron by limiting the court's role in deciding whether or not punitive damages have a regulatory effect, because it implicitly assumes that the effect exists and is substantial. Such an amendment, however, poses the same dilemma faced by the courts in Wilson v. Chevron Chemical Co. ${ }^{247}$ and Ferebee v. Cheuron Chemical Co.: ${ }^{248}$ given a federal law that purports to distribute regulatory power between federal and state authorities, how does a court respond to overlapping regulatory activities? To solve this dilemma, Congress should amend Section 24(b) to explicitly prohibit state regulation of labeling through punitive damages in failure-to-warn cases, pursuant to its supremacy clause power to allocate regulatory power between federal and state authorities. ${ }^{29}$ Alternatively and less drastically, Congress could enact a presumption in favor of preemption of punitive damages in failure-to-warn cases.

In addition, any amendment to FIFRA should also increase the fines and penalties associated with a violation of the statute. Increasing the costs of noncompliance with FIFRA would refocus manufacturer attention on the federal statute and reduce the conflict between state and federal law. Increasing the impact of FIFRA's punitive scheme, moreover, will give the statute greater regulatory effect, hopefully fulfilling some of the goals that state juries seek to achieve through puni-

248 One solution to the problem of disparate state laws is the enactment of uniform statutes. See Hart, The Relations Between State and Federal Law, 54 Colum. L. REv. 489, 538 (1954). "Here again, however, one of the main sticking points is the problem of securing uniform judicial interpretation." Id.

247 No. 83-762 (S.D.N.Y. Dec. 17, 1986).

248736 F.2d 1529 (D.C. Gir.), cert. denied, 469 U.S. 1062 (1984).

248 In the words of Chief Justice Warren, "[i]f Congress had specifically provided that the states were without power to award damages under such circumstances, or it had expressly sanctioned such redress in state courts, our course of action would be clear." Automobile Workers v. Russell, 356 U.S. 634, 647 (1967) (Warren, C.J., dissenting) (suggesting an amendment to the Taft-Hartley Act preempting a state's power to assess compensatory and punitive damages against a union for denying a worker access to a plant during a strike). 
tive awards, yet in a more efficient manner than is possible with a multitude of exemplary awards.

Finally, state legislatures could significantly limit the size of punitive damage awards. Indeed, a chorus of commentators has supported such a move for some time. ${ }^{250}$ Some legislatures already have moved in this direction, not for the purposes of reducing the conflict with federal statutes, but because the size of punitive awards is excessive. ${ }^{251}$ Reducing the size of these awards would at least weaken their regulatory effect and mitigate the consequences that flow from the disincentive to comply with FIFRA that such awards create. Nor will state regulation through large jury awards of punitive damages be missed. The federal effort to control pesticide manufacturers is clearly better financed, has the benefit of greater expertise, and provides a more effective comprehensive approach to promoting the safe use of pesticides than the efforts made by state courts. Federal regulation of labeling through the application of FIFRA will save these manufacturers from facing the costs and choices that accompany double regulation.

\section{Conclusion}

Wilson v. Chevron Chemical Company ${ }^{252}$ and Ferebee v. Chevron Chemical Company ${ }^{253}$ provide two recent examples of the ongoing doctrinal and practical conflict between a comprehensive federal law and the award of punitive damages in state failure-to-warn tort suits. This Comment argues that Congress both explicitly and implicitly intended FIFRA to preempt state efforts at labeling pesticide products by occupying this domain of regulation. Preemption is also proper because punitive damages have a regulatory effect that conflicts with the labeling provisions and the punitive scheme in the federal statute. The regulatory effect of large exemplary awards may discourage companies like Chevron from complying with FIFRA requirements and induce a vari-

${ }^{280}$ See, e.g., Duffy, supra note 195, at 4 ("The doctrine of punitive damages is an anomaly in the law. . . . [T] longer exists. The doctrine is an anachronism and should be abolished."); Wheeler, The Constitutional Case for Reforming Punitive Damages Procedures, 69 VA. L. Rev. $269,298-300$ (1983) (supporting statutes that limit punitive damages and "express the legislature's judgment about the optimal amount of civil punishment for the most egregious instances of a particular form of misconduct"); Note, supra note 183, at 1161 (arguing that in most cases criminal punishment more effectively deters undesirable conduct than do punitive damages).

${ }^{251}$ See, e.g., Florida Legislature Votes "Tort Reform" Aimed at Cutting Insurance Rates 40\%, Wall St. J., June 9, 1986, at 2, col. 3; Tort-Reform Movement Shifts to States, Wash. Post, Feb. 10, 1986, at 42, col. 2 (Washington Business section).

${ }_{252}$ No. 83-762 (S.D.N.Y. Dec. 17, 1986).

${ }^{283} 736$ F.2d 1529 (D.C. Cir.), cert. denied, 469 U.S. 1062 (1984). 
ety of other responses that ultimately will frustrate FIFRA's congressionally determined goals.

This Comment argues for preemption of punitive damage claims associated with failure-to-warn tort cases brought against manufacturers regulated by FIFRA. In addition, it proposes a number of legislative responses designed to resolve the preemption dilemma, such as an amendment to FIFRA that either prohibits state action that impacts labeling or explicitly preempts exemplary awards in failure-to-warn cases. Alternatively, Congress could increase the fines imposed on violators of FIFRA, thereby reducing the conflict created by complying with the federal law and paying exemplary fines. This legislation will both encourage the judicial response of preemption and affirmatively prevent the conflicts and costs that arise under the coexistence of FIFRA and punitive damages. 


$$
\text { - }
$$

